See discussions, stats, and author profiles for this publication at: https://www.researchgate.net/publication/257754299

\title{
The relationship between personal unsecured debt and mental and physical health: A systematic review and meta-analysis
}

Article in Clinical psychology review · September 2013

DOI: 10.1016/j.cpr.2013.08.009 · Source: PubMed

CITATIONS

READS

148

1,135

3 authors, including:

Thomas Richardson

Solent NHS Trust

110 PUBLICATIONS 1,719 CITATIONS

SEE PROFILE

Ron Roberts

Kingston University

78 PUBLICATIONS 1,555 CITATIONS

SEE PROFILE

Some of the authors of this publication are also working on these related projects:

Whitehall 2 View project

An evaluation of predictors of dropout from an Emotional Coping Skills programme in a community mental health service View project 


\section{Elsevier Editorial System(tm) for Clinical Psychology Review Manuscript Draft}

Manuscript Number: CPR-D-13-00068R1

Title: The relationship between personal unsecured debt and mental and physical health: A systematic review and meta-analysis

Article Type: Review Article

Keywords: Debt; Indebtedness; Financial; Health; Mental Health; Depression.

Corresponding Author: Mr Thomas H Richardson, B.A.(Hons)

Corresponding Author's Institution: University of Southampton, U.K.

First Author: Thomas Richardson, B.A.(Hons)

Order of Authors: Thomas Richardson, B.A.(Hons); Peter Elliott, BA, MSc, C Psychol, AFBPsS.; Ronald Roberts, $\mathrm{PhD}$

Abstract: This paper systematically reviews the relationship between personal unsecured debt and health. Psychinfo, Embase and Medline were searched and 52 papers were accepted. A hand and citedby search produced an additional 13 references leading to 65 papers in total. Panel surveys, nationally representative epidemiological surveys and psychological autopsy studies have examined the relationship, as have studies on specific populations such as university students, debt management clients and older adults. Most studies examined relationships with mental health and depression in particular. Studies of physical health have also shown a relationship with self-rated health and outcomes such as obesity. There is also a strong relationship with suicide completion, and relationships with drug and alcohol abuse. The majority of studies found that more severe debt is related to worse health; however causality is hard to establish. A meta-analysis of pooled odds ratios showed a significant relationship between debt and mental disorder ( $\mathrm{OR}=3.24)$, depression ( $\mathrm{OR}=2.77)$, suicide completion $(\mathrm{OR}=7.9)$, suicide completion or attempt $(\mathrm{OR}=5.76)$, problem drinking $(\mathrm{OR}=2.68)$, drug dependence (OR=8.57), neurotic disorder (OR=3.21) and psychotic disorders (OR=4.03). There was no significant relationship with smoking $(\mathrm{OR}=1.35$, $\mathrm{p}>.05)$. Future longitudinal research is needed to determine causality and establish potential mechanisms and mediators of the relationship. 
Dr Bellack,

Please find attached a response to the reviewer's comments and an amended manuscript. We hope that these changes address the concerns raised, and the paper can now be accepted for publication in Clinical Psychology Review.

Kind Regards,

Thomas Richardson

Peter Elliott

Ronald Roberts

Corresponding Author. Thomas Richardson. Address: Building 44a, University of Southampton, Highfield Campus, SO17 1BJ, UK. Email: thr1g10@ soton.ac.uk, Phone: 0044 (0)2380 595320 


\section{Highlights}

- A number of studies have shown a relationship between personal unsecured debt and health.

- This relationship is especially strong for mental health in particular depression.

- There are also relationships with substance use and suicide.

- Research suffers from inconsistent use of standardised measures.

- A lack of longitudinal studies makes it difficult to demonstrate causality. 
We would like to thank the reviewer for their detailed comments. In relation to these we have made the following changes, which have all been marked in the main manuscript via track changes:

- We have now clarified in the title, abstract, introduction, discussion and highlights that this examines personal unsecured debt specifically.

- In the Method, Search Procedure we have changed 'Classes' into 'Classed'

- In Appendix B (Characteristics of Panel Surveys) we have added 'years' to 4-6. The formatting of the tables meant that some words were cut off: this has now been corrected for all the tables.

- Page 17, fifth line of first paragraph, "self-related" has been changed to "self-rated."

- Page 19, second paragraph, a new paragraph has been started after the line beginning "The advantage."

- Page 20, first line of second paragraph, "somewhat unclear" has been changed to "unclear".

- Page 21, second paragraph, the first line has been amended to specify about 'personal, unsecured debt'.

- Page 5: more detail has been added to justify why studies on secured loans and mortgage debt were excluded.

- Results (Second paragraph of page 18): More detail has been added about heterogeneity in the meta-analysis. An additional analysis has been performed, whereby the models where changed to fixed effects to determine whether there were any large changes in effect sizes and consequently whether heterogeneity is problematic. As described in the paper, this had little impact on effect sizes for drug dependence or suicide completion or attempt, however it did have an impact on smoking and problem drinking effects sizes suggesting that heterogeneity is problematic for these two variables.

- Page 7 Method: A description of heterogeneity analysis has been added to the meta-analysis method.

- Page Introduction 4: A figure on outstanding credit card debt in the US has been added.

- Page 9: Abbreviations and references have been added to the 'measures used' section of the results.

- The discussion has been updated so that references are given when "studies" are referred to. 
The relationship between personal unsecured debt and mental and physical health: A systematic review and meta-analysis

Thomas Richardson $^{\mathrm{a} 1}$, Peter Elliott ${ }^{\mathrm{a},}$ Ronald Roberts ${ }^{\mathrm{b}}$

${ }^{\text {a }}$ Professional Training Unit, School of Psychology, University of Southampton, U.K.

${ }^{\mathrm{b}}$ Department of Psychology, Kingston University, U.K.

${ }^{1}$ Corresponding Author. Address: Building 44a, University of Southampton, Highfield

Campus, SO17 1BJ, UK. Email: thr1g10@ soton.ac.uk, Phone: 0044 (0)2380 595320 
DEBT AND HEALTH

\title{
The relationship between personal unsecured debt and mental and physical health: A
} systematic review and meta-analysis

\begin{abstract}
This paper systematically reviews the relationship between personal unsecured debt and health. Psychinfo, Embase and Medline were searched and 52 papers were accepted. A hand and cited-by search produced an additional 13 references leading to 65 papers in total. Panel surveys, nationally representative epidemiological surveys and psychological autopsy studies have examined the relationship, as have studies on specific populations such as university students, debt management clients and older adults. Most studies examined relationships with mental health and depression in particular. Studies of physical health have also shown a relationship with self-rated health and outcomes such as obesity. There is also a strong relationship with suicide completion, and relationships with drug and alcohol abuse. The majority of studies found that more severe debt is related to worse health; however causality is hard to establish. A meta-analysis of pooled odds ratios showed a significant relationship between debt and mental disorder $(\mathrm{OR}=3.24)$, depression $(\mathrm{OR}=2.77)$, suicide completion $(\mathrm{OR}=7.9)$, suicide completion or attempt $(\mathrm{OR}=5.76)$, problem drinking $(\mathrm{OR}=2.68)$, drug dependence $(\mathrm{OR}=8.57)$, neurotic disorder $(\mathrm{OR}=3.21)$ and psychotic disorders $(\mathrm{OR}=4.03)$. There was no significant relationship with smoking $(\mathrm{OR}=1.35, \mathrm{p}>.05)$. Future longitudinal research is needed to determine causality and establish potential mechanisms and mediators of the relationship.
\end{abstract}

Keywords: Debt, Indebtedness, Financial, Health, Mental Health, Depression. 
The relationship between personal unsecured debt and mental and physical health: A systematic review and meta-analysis

\section{Introduction}

A large body of literature has established that health problems, in particular mental health problems, are more prevalent in certain parts of society. Specifically, those of low 'socio-economic status' (SES) have been found to have increased risk of poor mental health (Amone-P'Olak, et al., 2009), depression (Lorant, et al., 2003), poor physical health and even death (Bosma, Schrijvers, \& Mackenbach, 1999; Mackenbach, et al., 2008). In the UK, areas of higher socio-economic deprivation have higher levels of deliberate self-harm (Hawton, Harriss, Hodder, Simkin, \& Gunnell, 2001), and psychiatric hospital admissions (Koppel \& McGuffin, 1999). A study of ten European countries demonstrated that socioeconomic deprivation increases the risk of suicide (Lorant, Kunst, Huisman, Costa, \& Mackenbach, 2005), and a study of 65 countries by the World Health Organisation found that rates of depression varied by levels of income equality. As a result there is "widespread albeit often implicit recognition of the importance of socioeconomic factors for diverse health outcomes" (Braveman, et al., 2005), with many studies either looking at the effects of SES on health directly, or controlling for it as a potential confounding variable (Braveman, et al., 2005).

However in recent years a number of studies have begun to examine what specific aspects of low socio-economic status are related to adverse health outcomes. Unemployment specifically has been found to be related to mental illness and suicide (Almasi, et al., 2009; Amoran, Lawoyin, \& Oni, 2005; Andersen, Thielen, Nygaard, \& Diderichsen, 2009; Corcoran \& Arensman, 2011; Heimo Viinamäki, 2000; Qin, Agerbo, \& Mortensen, 2003). Income levels have also been found to be related to both depression (Andersen, et al., 2009; Wang, Schmitz, \& Dewa, 2010) and suicide (Qin, et al., 2003). A systematic review 


\section{DEBT AND HEALTH}

suggested that wealth is related to health, and the authors suggest this should be used as an indicator of SES (Pollack, et al., 2007). Financial difficulties such as being unable to pay the bills also appear to be related to mental health (Butterworth, Rodgers, \& Windsor, 2009; Husain, Creed, \& Tomenson, 2000; Elina Laaksonen, et al., 2007; E. Laaksonen, et al., 2009), and physical health variables such as smoking (Kendzor, et al., 2010). Butterworth, Olesen, and Leach (2012) conclude that financial hardship might explain the relationship between SES and depression. Studies have also shown that traditional indicators of SES such as parental occupation, education and occupation class are often weakly related to mental health (Andersen, et al., 2009; M. Laaksonen, Rahkonen, Martikainen, \& Lahelma, 2005; Lahelma, Laaksonen, Martikainen, Rahkonen, \& Sarlio-Lähteenkorva, 2006). It has also been suggested that measures of SES are often not related to each other, for example correlations between education and income are moderate and differ by ethnicity (Braveman, et al., 2005). Such measures may also change over time and depending on the population studied (Shavers, 2007). For example, income may be an inaccurate indicator of SES in students or those who are retired.

One potentially important socio-economic variable which is often overlooked in the literature is that of debt. Debt levels are greater in poorer families (Wagmiller, 2003), and traditional measures of SES such as income and education levels are related to level of debt (Bridges \& Disney, 2010), suggesting that debt may explain some of the relationships between SES and health. In addition, levels of debt have increased dramatically in recent years. There is currently around $£ 156$ billion in unsecured debt in the UK, and this is predicted to increase (Credit Action, 2013). Currently the average UK family owes more than $£ 11 \mathrm{k}$ in unsecured debt (AVIVA, 2013). Similarly in the US there is currently $\$ 660$ billion in outstanding credit card debt (Federal Reserve Bank of New York, 2013) 
There has been a previous review into personal debt and mental health (Fitch, Hamilton, Bassett, \& Davey, 2011). However this did not examine relationships with physical health, although the literature shows a strong relationship between physical and mental health (Scott, et al., 2009), and did not examine relationships with substance use. This systematic review therefore aims to review all studies which examine the relationship between personal unsecured debt and physical and mental health, suicide and substance use.

\section{Method}

\section{Databases and Search Terms}

Three databases were searched: Psychinfo, Medline and Embase. The following search terms were used to search all fields: 'Indebtedness' or 'Debt' and 'Health' or 'Mental disorder' or 'Mental illness' or 'Depression' or 'Anxiety' or 'Stress' or 'Distress' or ‘Alcohol' or 'Drug' or 'Suicide' or 'Eating Disorder' or 'Psychosis' or 'Schizophrenia'.

\section{Inclusion and Exclusion Criteria}

The following inclusion criteria were used. Papers had to examine the relationship between personal debt and physical health, mental health, drug or alcohol problems or suicide. References had to be full papers written in English in a peer reviewed journal. Only research studies were included: reviews, meta-analyses or letters/commentaries on the area were excluded. Papers were not excluded on the basis of year of publication, study design, measures used, participant characteristics or sample size.

Papers had to look specifically at the impact of personal unsecured debt for example credit card debt, student loans, and being behind in payments to utility companies. Studies which looked only at the impact wider economic variables such as financial stress or income were excluded. Studies on the impact of secured loans or mortgages were excluded as 
DEBT AND HEALTH

secured loans are a different type of debt, and it would create a too wide scope for the review

$\underline{\text { to include this. }}$

Papers also needed to employ a comparative element in the analysis, for example comparing the prevalence of a health problem in populations with and without debt. Studies which for example simply reported the percentage of those with debt who had a health problem were excluded. Alternatively if there was no comparison, papers could be included if there was a correlation analysed, for example showing that the severity of a health problem increased as the level of debt increased.

Studies on suicide and debt were only included if they showed a relationship between debt and suicidal completion or suicidal ideation. Studies which for example conducted cluster analyses to demonstrate that debt related suicides were related to a specific method of suicide were excluded. For papers which examined the relationship between debt and stress, studies which used measures of financial stress only were excluded: measures had to be of more global stress. Studies on health behaviours, for example relationship unprotected sex or lack of exercise were only included if they related these to health outcomes.

\section{Search procedure}

References were initially screened at title to see whether they met inclusion criteria. If accepted at title the abstract was screened, and if this was accepted the full paper was screened. Reasons for rejection were noted during the search. Main reasons for rejection noted were: not relevant/multiple reasons, not debt specific, Review/Meta-analysis/Letter, not in English, not full paper/not peer reviewed, Duplicate (found in previous search), or Other. Only one main reason for rejection was noted, if there were multiple reasons then the paper was classeds as not relevant/multiple reasons. Included papers were then hand-searched for 
DEBT AND HEALTH

any additional references. A cited-by search was also conducted to identify references which had cited the included papers.

\section{Meta-Analysis Method}

All included papers was screened for relevant data which could be subjected to a meta-analysis in the form of number of participants in different categories to be used for pooled unadjusted odds ratios, or means, SDs and sample sizes which could be used for meta-analysis of the standardised mean difference. All variables where sufficient data was reported for analysis by two or more studies were included. If insufficient detail was given in the paper but the data was otherwise appropriate, authors were contacted for additional details. For example if the paper had reported the Odds Ratio for debt in those with and without depression, the author was contact for details on the sample sizes upon which this was based. Studies had to report differences in the prevalence or severity of health conditions based on debt versus no debt. Where there was more than one group data was pooled, for example if the prevalence in debt in those with severe depression and mild to moderate depression were given, this was combined into a single depression category. If more than one set of data which could not be pooled was given by a single study, then this was included in the meta-analysis as if it were two studies, and total sample size was adjusted accordingly. There was insufficient continuous data for analysis using standardised means. All categorical data was pooled into unadjusted odds ratios, using a Haenszel random effects model weighted by sample size with $95 \%$ confidence interval and statistical significance set at $p<.05$. Results were computed via Review Manager 5 (Cochrane, 2008). A heterogeneity analysis was conducted to determine the extent of variation in effect sizes between the individual studies. $\underline{\text { Random effects models were used for all analyses to account for possible heterogeneity. }}$ 


\section{Results}

\section{Results of the Search}

A flow diagram of the systematic search is shown in figure 1 . The search terms on the three databases produced a total of 3314 papers, from which 219 abstracts were screened. Seventy-three full papers were then screened of which 52 were accepted. Four additional papers were identified via hand search and nine from a cited by search leading to 65 papers included in total.

\section{Characteristics of studies}

Appendices A-I display the characteristics of studies in terms of country, design, sample, measures used, main findings and confounds controlled for. Please note that main findings shown are only those which remain after adjustment for confounds, if applicable. In addition the measures used reported are only for those relevant to debt and health. The studies were classed into a number of different categories. These were panel surveys $(n=6)$, nationally representative surveys $(n=11)$, psychological autopsy studies $(n=4)$, studies with students ( $n=13)$, studies with other specific populations $(n=22)$, and other $(n=7)$. The specific populations included studies with health service users $(n=8)$, parents $(n=2)$, ethnic minorities $(n=4)$, farmers $(n=2)$, older adults $(n=4)$ and problem gamblers $(n=2)$.

The studies were predominantly conducted in the UK $(n=21)$ or US $(n=21)$, with one being conducted in both the UK and Finland. Four studies were conducted in Australia, four in China (Hong Kong), four in India and three in Germany. One study per country was conducted in New Zealand, the Netherlands, Finland, Thailand, Uganda, Austria and Japan. In terms of design, 43 were cross-sectional and 13 were longitudinal. The length of follow-up in the longitudinal studies ranged from 6 months to 23 years with a median of 6 years. There 
DEBT AND HEALTH

were also four cross-sectional cohort studies, and on case-series intervention trial. Sample sizes ranged from 43 to 66,664 with a median of 1941 participants. Twenty-nine of the studies were retrospective analyses of existing data.

\section{Measures Used}

Thirty-four of the studies examined only mental health, whilst nine physical health only, and eight both physical and mental health. Eight examined suicide, and one both mental health and suicide. One study examined death as its dependent variable. Thirteen studies examined tobacco, alcohol or drug use in addition to physical or mental health, whilst three studies solely examined substance use. Four studies examined weight (BMI) in addition to other health variables, whilst one study examined only weight. Forty-five studies used standardised measures of health, whilst 19 did not and relied on author-constructed questions or self-rated health. Studies examining physical health were more likely not to use standardised measures (8/9 studies) than studies examining mental health (4/34 studies).

The most commonly used measure of mental health was the Clinical Interview Schedule Revised-_(CIS-R, Lewis, Pelosi, Araya, \& Dunn, 1992) which was used by (13 studies.), Tthe General Health Questionnaire_(GHQ, Goldberg, 1991) was used in nine, the Centre for Epidemiological Studies Depression Scale_(CES-D, Radloff, 1977) in five studies, and the Beck Depression Inventory_(BDI, Beck, Ward, Mendelson, Mock, \& Erbaugh, 1961) in three. The Short Form Health Survey (SF-36 or SF-12Ware, 1993) was used in five studies to measure both physical and mental health.

\section{General Findings}

A total of 43 of the studies used multiple regression to control for potential confounding variables such as demographics. Overall $78.5 \%(\mathrm{n}=51)$ of the studies reported 
DEBT AND HEALTH

that being in debt was related to worse health. Seven studies found no effect, whilst two found that debt was related to better health. Three studies found an effect for worry about debt rather than debt per se, whilst two found that financial strain rather than debt was related to health.

\section{Studies with Students}

Thirteen studies looked at the relationship between debt and health in university students, primarily in the UK and US. The details are summarised in appendix A. Many of the studies in the US consisted of secondary analyses of existing data sets from large national surveys, and hence had large sample sizes, for example Adams and Moore (2007) had more than forty thousand participants. However these larger studies tended to rely on author constructed questions on health. The US studies also tended to focus on other health risk behaviours, such as unprotected sex and drink-driving, and also focused on credit card debt specifically. Studies in the UK had smaller sample sizes, but all used a standardised measure of mental or physical health. Across the thirteen studies, there was one which was longitudinal (Cooke, Barkham, Audin, Bradley, \& Davy, 2004), which followed British students across the three years of their degree. There was also a cohort study, which compared UK students to students in Finland where tuition fees are lower (Jessop, Herberts, \& Solomon, 2005). Demographics such as age and gender were controlled for by many studies, though six studies did not control for any variables. No study controlled for socioeconomic status or other economic variables.

In terms of findings, those with higher debt or financial concern were more likely to smoke (Berg, et al., 2010; Jessop, et al., 2005; Roberts, et al., 2000; Roberts, Golding, Towell, \& Weinreb, 1999; Stuhldreher, Stuhldreher, \& Forrest, 2007) and drink excessively (Nelson, Lust, Story, \& Ehlinger, 2008; Stuhldreher, et al., 2007), though (Jessop, et al., 
2005) and Ross, Cleland, and Macleod (2006) found no effect. They were also more likely to use drugs (Adams \& Moore, 2007; Nelson, et al., 2008; Roberts, et al., 2000; Stuhldreher, et al., 2007), though Adams and Moore (2007) found those in debt were less likely to have used cannabis. It is important to note the differences in how debt groups were defined, for example (Norvilitis, Szablicki, \& Wilson, 2003) looked at debt-to-income ratio, whilst Roberts, et al. (1999) compared those who had considered dropping out for financial reasons, Adams and Moore (2007) compared groups based on level of credit card debt and Stuhldreher, et al. (2007) examined those with past gambling related debt. Debt was found to be related to higher scores on the SF-36, a measure of both physical and mental health by four studies (Carney, McNeish, \& McColl, 2005; Jessop, et al., 2005; Roberts, et al., 2000; Roberts, et al., 1999), and higher scores on the GHQ, a measure of global mental health (Roberts, et al., 2000; Roberts, et al., 1999). However Ross, et al. (2006) found that those with higher GHQ scores had lower debts.

Stuhldreher, et al. (2007) found that those with past debt were more likely to score positive for depression on the BDI, and report higher stress levels. Norvilitis, et al. (2003) reported that debt-to-income ratio and attitudes to debt did not predict stress but financial well-being did. (Nelson, et al., 2008) also reported greater body dissatisfaction in those with debt, and Adams and Moore (2007) reported higher BMI. Cooke, et al. (2004) used the CORE, a measure of global mental health to demonstrate that higher scores were related to levels of debt worry and financial concern. Finally, Roberts et al $(1999 ; 2000)$ conducted path analyses demonstrating that amount of debt let to worse mental health via considering abandoning university and working longer hours. Lange and Byrd (1998) similarly found that debt levels led to anxiety and depression via increase financial stress and strain, and cognitions such as locus of control around finances. 


\section{DEBT AND HEALTH}

\section{Panel Surveys}

A total of five panel surveys were included, these are summarised in appendix B. All of these analysed existing data from wider studies, typically from an economic perspective on predictors of debt. They typically had sample sizes of several thousand, and all controlled for potential confiding demographic variables. The collection of data at multiple time points was also a major strength. However they typically suffered from crude measures of health, with only two using standardised measures (Brown, Taylor, \& Price, 2005; Keese \& Schmitz, 2012).

Bridges and Disney (2010) found that debt, including past debt increased the risk of depression, and Brown, et al. (2005) found a relationship with higher GHQ scores. Gathergood (2012) similarly found that those heavy debt repayments predicted higher GHQ scores. Brown, et al. (2005) found a dose-response effect with more debts increasing risk further, whilst Bridges and Disney (2010) found no such effect. (Caputo, 2012) found those in debt were more likely to have physical health problems, whilst Webley and Nyhus (2001) reported more smoking, alcohol use, and greater risk of obesity. Subjective views of debts were found to be important, with subjective stress about debt being more important than objective measures of debt (Bridges \& Disney, 2010), and believing finances will get worse predicting poor mental health (Brown, et al., 2005).

\section{Psychological Autopsy Studies}

Four studies, all conducted in Hong Kong, used psychological autopsy of suicide completers to examine the prevalence of debt compared to age matched community controls. These are shown in Appendix C. These typically examined a number of different predictors of suicide, with multiple regression models including factors such as marital status, psychiatric diagnoses as well as debt. All but one therefore controlled for potential 
DEBT AND HEALTH

confounds, by examining whether the effect of debt was independent of other variables. These all looked at the presence of unmanageable debt, which was defined as more than four years to repay given monthly income and expenses (P.W.Wong, Chan, Conwell, Conner, \& Yip, 2010). P. W. Wong, et al. (2010) simply reported descriptive statistics with a higher proportion on unmanageable debt in suicide completers. The remaining studies reported adjusted Odds Ratios for debt and suicide completion of 7.9 to 9.5 (Chan, et al., 2009; Chen, et al., 2006; P. W. C.Wong, et al., 2008). (Chan, et al., 2009) further estimated that $23 \%$ of suicide was attributable to debt. 
DEBT AND HEALTH

\section{Nationally Representative Surveys}

Ten papers were epidemiological studies with nationally representative samples of the general population. These are shown in appendix D. Seven were conducted in the UK, six of which were secondary analysis of data from the British National Psychiatric Morbidity Survey. All but one (Jenkins, Fitch, Hurlston, \& Walker, 2009) controlled for confounds, and all but one (Lyons \& Yilmazer, 2005) used standardised measures. However all but one (Polprasert, Sawangdee, Porrapakham, Guo, \& Sirirassamee, 2006) were cross-sectional, making causality hard to establish.

Studies in the UK all found that being in debt was related to an increased risk of Common Mental Disorders with adjusted Odds Ratios after controlling for confounds of between 1.9 (Clark, et al., 2012) and 2.8 (Meltzer, Bebbington, Brugha, Farrell, \& Jenkins, 2013). Jenkins, Fitch, et al. (2009) reported descriptive statistics only, as did Hintikka, Kontula, Saarinen, Tanskanen, Koskela, and Viinamäki (1998) who reported a greater likelihood of scoring above cut-off on the GHQ in those with debt. Effects were found for neurotic disorders, psychotic disorders, alcohol and drug dependence specifically (Jenkins, Bebbington, et al., 2009; Jenkins, et al., 2008; Meltzer, et al., 2013) as well as depression (Meltzer, et al., 2010; Zimmerman \& Katon, 2005). Dose-response effects were also found for number of debts and risk of mental disorder (Jenkins, et al., 2008; Meltzer, et al., 2013). Meltzer, et al. (2011) reported that debt increased the risk of suicidal ideation in a doseresponse fashion. Hintikka, Kontula, Saarinen, Tanskanen, Koskela, and Viinamaki (1998) similarly found that debt problems increased the risk of suicidal ideation, but there was no relationship with attempts. Lyons and Yilmazer (2005) found no relationship between debt and self-reported health, whilst a longitudinal study by Polprasert, et al. (2006) found that debt did not predict death from disease in Thailand. Balmer, Pleasence, Buck, and Walker 
(2006) found that long term illness or disability increased the likelihood of legal problems resulting from debt.

\section{Health Service User Populations}

Six studies examining health service user populations are shown in appendix E. As specific populations were studied sample sizes were inevitably small, ranging from 43 to 87 . Standardised measures of health were used in all of these studies, however only two controlled for confounds. Patel, et al. (1998) and Pothen, Kuruvilla, Philip, Joseph, and Jacob (2003) found that debt increased the risk of common mental disorders and depression specifically amongst primary care attenders in India after controlling for demographics. Abbo, et al. (2008) found that those attending traditional healers were more likely to be psychologically distressed if they were in debt. Hatcher (1994) examined self-harmers, finding higher levels of depression, psychiatric diagnosis and suicidal intent in those with debt. Finally Battersby, Tolchard, Scurrah, and Thomas (2006) found that pathological gamblers with gambling-related debt were more likely to have suicidal ideation, whilst Maccallum and Blaszczynski (2003) found no relationship between amount of debt and suicidal ideation in gamblers.

\section{Debt Management Clients}

Four studies examined the health of those undergoing debt counselling; these are shown in appendix F. Two cohort studies compared over-indebted clients to the general population, finding an increased likelihood being overweight and reporting back pain after controlling for confounds (Munster, Ruger, Ochsmann, Letzel, \& Toschke, 2009; Ochsmann, Rueger, Letzel, Drexler, \& Muenster, 2009). O’Neill, Sorhaindo, Xiao, and Garman (2005) found that self-rated health was linked to reduced debts after a debt management intervention. 
Selenko and Batinic (2011) found that financial strain, but not amount of debt was related to mental health as measured by the GHQ.

\section{Older adults}

Four studies examined relationships between debt and health in older adults; these are shown in appendix G. All of these used data from existing wider studies, and therefore had large sample sizes. Debt was found to increase the risk of depression as measured by the CES-D after controlling for confounds (Drentea \& Reynolds, 2012; Kaji, et al., 2010; Lee \& Brown, 2007). However Drentea and Reynolds (2012) found this relationship was moderated by stress about debt. Drentea and Reynolds (2012) also found a relationship with selfreported anxiety. (Lee, Lown, \& Sharpe, 2007) found no relationship between self-rated health and debt.

\section{Other Specific Populations}

Eight studies focused on other specific populations. These are shown in appendix H. All these studies controlled for confounds, but only four used standardised measures. Three studies focused on parents. One found debt increased risk of Common Mental Disorders (CMD) but not depression in mothers and fathers (Cooper, et al., 2008). In a study examining financial hardship in lone mothers, Hope, Power, and Rodgers (1999) found that in women overall, debt was linked to being high risk for depression. Another smaller longitudinal study found that debt was related to post-natal depression, but that worry about debt was more important than amount of debt (Reading \& Reynolds, 2001). Four studies looked at Ethnic minority populations in the US. Drentea (2000) and Drentea and Lavrakas (2000) sampled from the general population but picked areas with a higher proportion of ethnic minorities, finding a relationship between a number of debt variables and self-rated health and anxiety. 
Yao, Sharpe, and Gorham (2011) found a non-significant trend for better self-rated health to increase the likelihood of debt, whilst $\mathrm{Xu}$ (2011) found that debt increased psychological distress only in specific ethnicities. Finally two studies looked at farmers. A large study found that debt problems predicted better self-rated health (Berry, Hogan, Ng, \& Parkinson, 2011), whilst a smaller study using the CES-D found a recent increase in debt increased the likelihood of depression (Beseler \& Stallones, 2008).

\section{Other Studies}

A further seven studies examined the relationship between debt and health but did not fit into any of the above categories. These are shown in appendix I. Elbogen, Johnson, Wagner, Newton, and Beckham (2012) found that military veterans post-deployment with mental health problems or brain injury were more likely to have large unsecured debts, whilst Finlay-Jones and Eckhardt (1984) found that debt increased the likelihood of being above the cut-off on the GHQ in unemployed young adults. Kassim and Croucher (2006) found that in Khat (amphetamine) users, those in debt to the dealer were more likely to be dependent. In a longitudinal study Molander, Yonker, and Krahn (2010) found that debt had little impact on changes in drinking over time, though debt increased the likelihood of stopping heavy drinking. In a large survey in India, Patel, et al. (2005) found that women were in debt were more likely to have Chronic Fatigue Syndrome. Hainer and Palesch (1998) found no relationship between debt and depression in junior doctors. Saxena, Sharma, and Maulik (2003) found that Indian families with a heavy drinker were more likely to be in debt. Finally, Turvey, Stromquist, Kelly, Zwerling, and Merchant (2002) found that a rural US population were more likely to have suicidal thoughts if they had an increase in debt. 
DEBT AND HEALTH

\section{Meta-Analysis Results}

A meta-analysis was conducted to determine pooled odds ratios for variables reported by multiple studies. The results are shown in table 1 . There was a statistically significant relationship between debt and presence of a mental disorder, depression, suicide completion, suicide completion or attempt, problem drinking, drug dependence, neurotic disorders (Depression, OCD, Panic, Phobia, GAD), and psychotic disorders. The only variable where there was not a significant difference was smoking.

There was significant heterogeneity in the odds ratios for the individual studies for $\underline{\text { suicide completion and attempt, smoking, problem drinking and drug dependence. A random }}$ effects model was used to account for possible heterogeneity. Changing this to a fixed model had little impact on the effect size for the analysis on drug dependence and suicide completion or attempt. However had a big impact on effect sizes for smoking and problem drinking, thus for these two variables heterogeneity is problematic.

\section{Discussion}

The aim of this paper was to systematically review all the literature examining the relationship between personal unsecured debt and health. A relatively large number of studies were found to examine this relationship, though many of these examined debt in addition to other variables, and few examined debt specifically. The majority of these studies examined relationships with mental health, with most studies on physical health consisting of selfrelated-rated health as opposed to more objective measures of health (Berry et al., 2011; Lee et al., 2007; Lyons \& Yilmazer, 2005; O’Neill et al., 2005; Yao et al., 2011). The research at present consists of a number of different types of research with nationally representative surveys, panel surveys, psychological autopsy studies, and studies with specific populations 
such as students, older adults and debt management clients all examining the relationship between debt and health.

Overall the results suggest that being inunsecured debt increases the risk of poor health, with some studies showing a dose-response effect with more severe debt being related to more severe health difficulties_(Jenkins et al., 2008; Meltzer et al., 2011; 2013). Specifically in terms of physical health debt has been linked to a poorer self-rated physical health (O’Neill et al., 2005), long term illness or disability (Balmer et al., 2005), chronic fatigue (Patel et al., 2005), back pain_(Ochsmann et al., 2009), higher levels of obesity, (Webley \& Nyhus, 2001), and worse health and health related quality of life as measured by the SF-36. No studies have shown a relationship between debt and death other than via suicide, in contrast to previous findings of a relationship between SES and mortality (Mackenbach, et al., 2008). Debt also appears to be more common in suicide completers ;(Chan et al., 2009; Chen et al., 2006; Wong et al., 2008; 2010), and increases the risk of suicidal ideation and attempts-after controlling for possible confounds such as mental illness (Hintikka et al., 1998; Meltzer et al., 2011). Individual studies have shown a relationship with drug use, problem drinking and drug dependence as well as-tobacco smoking (Berg et al., 2010; Jenkins et al., 2008; Meltzer et al., 2013; Nelson et al., 2008; Roberts et al., 1999; 2000; Stuhldreher et al., 2007; Webley \& Nyhus, 2001). In terms of mental health, many studies have shown a relationship with common mental disorders (Clark et al., 2012; Cooper et al., 2008; Meltzer et al, 2013; Patel et al., 1998; Pothen et al., 2003), and global mental health as measured by the General Health Questionnaire (Goldberg, 1991Brown et al., 2005; Finlay-Jones \& Eckhardt, 1984; Gathergood, 2012; Hatcher, 1994; Hintikka et al., 1998;

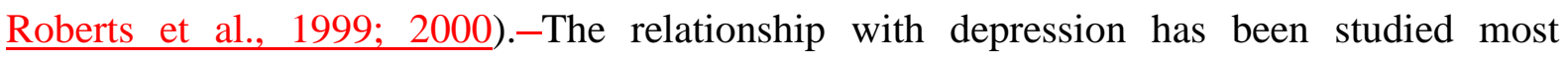
frequently and relationships appear to be strong and robust when assessed using standardised $\underline{\text { measures and controlling for possible confounds (Besler \& Stallones, 2008; Kaji et al., 2010; }}$ 
DEBT AND HEALTH

Meltzer et al., 2010; 2013; Pothen et al., 2003; Stuhldreher et al., 2007).--There is also limited evidence for a relationship with problems such as anxiety_(Drentea, 2000; Drentea \& Reynolds, 2012; Meltzer et al., 2013) and psychosis (Jenkins et al., 2008; 2009).-One study has shown a relationship with poorly measured body dissatisfaction_(Nelson et al., 2008), though there are no studies on eating disorder symptoms. The relationships between SES and eating disorders is however not as clear as other mental health problems; a large study found no effect of socioeconomic variables on the prevalence of eating disorders in adolescents (Swanson, Crow, Le Grange, Swendsen, \& Merikangas, 2011).

Despite a relatively large body of literature, there are a number of limitations with the evidence base at present. The main problem with the current research is that the vast majority of studies are cross-sectional, meaning that causality cannot be established. Most current studies simply show a relationship between health and debt, though which effects which is unclear. It might be that for example debt induces symptoms of depression. However it might also be that those who are depressed are more prone to debt due to greater levels of unemployment or poor financial management. The studies which are longitudinal generally are less likely to have standardised measures of health (Bridges \& Disney, 2010; Caputo, 2012; Keese \& Schmitz, 2012; Webley \& Nyhus, 2001). Thus more longitudinal research using standardised measures are needed to examine relationships across time between debt and health. There are also no prospective cohort studies at present, though these represent a unique opportunity to compare the health of groups who differ on levels of debt across time. Many studies rely on self-rated health (For example Berry et al., 2011; Lee et al., 2007; Lyons \& Yilmazer, 2005), which is prone to bias. Whilst many studies control for a number of potential confounding variables this is not always the case. There are also very different definitions of debt used in the literature. Some compare groups based on high versus low debtpresence or absence of credit card debt (Berg et al., 2010), some examine over- 
indebtedness as defined by a mathematical formula_(Wong et al., 2010), whilst others examine debt as being behind on bill paymentshaving a utility disconnected due to nonpayment (Jenkins et al., 2009). Some also look at gambling related-debt specifically (Bettersby et al., 2006; Maccallum \& Blaszcczynski, 2003; Stuhldreher et al., 2007)-which might have very different correlates to other forms of debt. This means it is somewhat difficult to compare these studies in terms of the health outcomes they demonstrate.

The results of the meta-analysis largely confirm the results of individual studies, showing a strong relationship with overall mental disorder, depression, suicide completion or attempt, problem drinking, drug dependence, neurotic disorders and psychotic disorders. The only variable which was not significant was smoking. Odds ratios demonstrate more than a three-fold risk of a mental disorder in those with debt, or alternatively a three-fold risk of debt in those with a mental disorder. Even stronger effects were shown for suicide with completers having nearly an eight-fold risk of debt.

The advantages of this meta-analysis are the pooled sample sizes of several thousand. However it is important to note the limitations of this meta-analysis. Firstly, only a few studies provided sufficient data on similar areas to be included. Thus for some of the analyses only two studies are used, and all data is categorical, with no data available on continuous variables such as standardised measure scores. Secondly, as these are unadjusted pooled odds ratios the effects of confounding variables are not controlled for. Thirdly, for suicide completion and attempt, smoking, problem drinking and drug dependence there is significant heterogeneity in the odds ratios for the individual studies, thus the pooled odd ratios may be unreliable and should be interpreted with caution. smoking and problem drinking there was $\underline{\text { significant heterogeneity and so the results should be interpreted with caution. }}$

Finally, it is important to note that the outcomes measured differed somewhat. For example mental disorder was defined as above the cut-off on the GHQ (Finlay-Jones \& 
Sckhardt, 1984; Hintikka et al., 1998), or meeting the diagnostic criteria based on the CIS-R

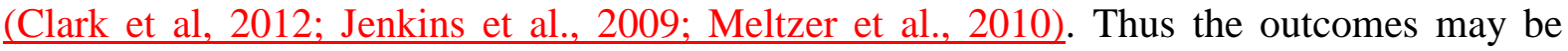
slightly different. Similarly debt is defined differently. For example for the analysis on problem drinking, Jenkins, et al. (2008) defined debt as being currently behind on a tax or bill, whereas Stuhldreher, et al. (2007) look at those who have been in debt due to gambling. Thus the measures of debt are also not equivalent, which may explain the observed heterogeneity of findings.

The specific mechanisms by which_personal unsecured debt is related to health are still somewhat-unclear in the current literature. However a number of studies demonstrated that, in terms of relationships with mental health such as depression, psychological elements appear to be important. For example subjective aspects of debt such as worry and stress about debt (Cooke et al., 2004; Drentea \& Reynolds, 2012), considering dropping out of university due to debt (Roberts et al., 19991 2000), hopelessness (Meltzer et al., 2011), financial concern $\underline{\text { (Cooke et al., 2004; Jessop et al., 2005), locus of control around finances_Lange \& Byrd, }}$ 1998), -or believing finances will worsen (Brown et al., 2005) are related mental health. In addition some studies demonstrate they are more important that objective measures such as amount of debt (Bridges \& Disney, 2001; Reading \& Reynolds, 2001), and may mediate the relationship between debt and health (Jessop et al., 2005; Meltzer et al., 2011).

However there are few longitudinal studies on the area thus it is unclear whether these variables such as worry about debt lead to poor mental health, or whether those with poor mental health are more likely to worry about their debt. The one longitudinal study on this (Reading \& Reynolds, 2001), found that the effect of worry about debt on later depression disappeared when baseline depression was controlled for, suggesting that poor mental health increases the likelihood of worry about debt. There is also some evidence that the relationship may be due to financial strain, rather than debt per se (Lange \& Byrd, 1998; Selenko \& 
DEBT AND HEALTH

Batinic, 2011). This area needs further research, however it suggests, at an epidemiological level, that recent increases in personal debt in the UK (Credit Action, 2013), may only impact mental health if they lead to an increase in stress and worry about debt. This is also encouraging as it means that psychological interventions such as Cognitive Behavioural Therapy might be able to reduce worry about finances and catastrophising, and thus attenuate the impact of debt on mental health.

A number of limitations of this systematic review need to be acknowledged. Only three databases were searched, though the relatively small number of papers found via a hand and cited-by search suggest that the search was comprehensive. Only personal debt such as credit card debt was used, and relationships with secured loans or mortgage debt were not examined. Previous research has shown that those with a mortgage generally have lower levels of psychological distress than those renting (Cairney \& Boyle, 2004), however problems with mortgage repayments such as being in arrears have been found to increase the risk of poor mental health (Taylor, Pevalin, \& Todd, 2007). As mortgage debt is a different type of debt it is beyond the scope of this review to examine this. However, as previously acknowledged debt is defined very differently in the literature meaning it is hard to conclude whether health problems are related to any debt, or only problematic debt or specific types of debt.

Nonetheless this review suggests that personal unsecured debt is related to health, and is therefore important to consider by health professionals. Wahlbeck and McDaid (2012) suggest that during the recent recession, a holistic view of mental health is needed with for example debt relief programmes in addition to input from mental health services. The Royal College of Psychiatrists has also recently publicised the issue (Fitch, 2006), suggesting that mental health professionals ask about debt and consider it as a potential cause of problems. During the recession the UK government has funded additional psychological therapy for 
DEBT AND HEALTH

those suffering from financial stress, and suggested that health services offer debt advice (Jenkins, Fitch, et al., 2009). However there is little research on how the impact of debt on health might be reduced. For example increasing repayment flexibility and offering debt advice have been found to reduce stress and increase optimism about finances (Field, Pande, Papp, \& Park, 2012; Pleasence \& Balmer, 2007), however whether this impacts on health is unclear. The specific mechanisms by which debt is related to health are therefore key to examine in further research in order to develop preventative interventions both to ensure that those with poor health are not at greater risk of problem debt, and that those in debt are not at a greater risk of developing mental health problems.

\section{Acknowledgements}

Thank you to all authors who provided extra data for the meta-analysis. 


\section{References}

Abbo, C., Ekblad, S., Waako, P., Okello, E., Muhwezi, W., \& Musisi, S. (2008). Psychological distress and associated factors among the attendees of traditional healing practices in Jinja and Iganga districts, Eastern Uganda: a cross-sectional study. International Journal of Mental Health Sysetems, 2, 16.

Adams, T., \& Moore, M. (2007). High-risk health and credit behavior among 18-to 25-yearold college students. Journal of American College Health, 56, 101-08.

Almasi, K., Belso, N., Kapur, N., Webb, R., Cooper, J., Hadley, S., Kerfoot, M., Dunn, G., Sotonyi, P., Rihmer, Z., \& Appleby, L. (2009). Risk factors for suicide in Hungary: a case-control study. BMC Psychiatry, 9, 45.

Amone-P'Olak, K., Ormel, J., Huisman, M., Verhulst, F. C., Oldehinkel, A. J., \& Burger, H. (2009). Life stressors as mediators of the relation between socioeconomic position and mental health problems in early adolescence: the TRAILS study. Journal of the American Academy of Child \& Adolescent Psychiatry, 48, 1031-38.

Amoran, O. E., Lawoyin, T. O., \& Oni, O. O. (2005). Risk factors associated with mental illness in Oyo State, Nigeria: a community based study. Ann Gen Psychiatry, 4, 19.

Andersen, I., Thielen, K., Nygaard, E., \& Diderichsen, F. (2009). Social inequality in the prevalence of depressive disorders. Journal of Epidemiology and Community Health, $63,575-81$.

AVIVA. (2013). The Aviva Family Finances Report. January 2013. Retrieved 05/02/2013 from www.aviva.com/data/reportlibrary/Family_Finances_Report_Jan_2013.pdf/

Balmer, N., Pleasence, P., Buck, A., \& Walker, H. C. (2006). Worried Sick: The Experience of Debt Problems and their Relationship with Health, Illness and Disability. Social Policy and Society, 5, 39-51.

Battersby, M., Tolchard, B., Scurrah, M., \& Thomas, L. (2006). Suicide ideation and behaviour in people with pathological gambling attending a treatment service. International journal of mental health and addiction, 4, 233-46.

Beck, A. T., Ward, C. H., Mendelson, M., Mock, J., \& Erbaugh, J. (1961). An inventory for measuring depression. Archives of General Psychiatry, 4, 561.

Berg, C. J., Sanem, J. R., Lust, K. A., Ahluwalia, J. S., Kirch, M. A., \& An, L. C. (2010). Health-related characteristics and incurring credit card debt as problem behaviors among college students. The Internet Journal of Mental Health, 6.

Berry, H. L., Hogan, A., Ng, S. P., \& Parkinson, A. (2011). Farmer health and adaptive capacity in the face of climate change and variability. Part 1: Health as a contributor to adaptive capacity and as an outcome from pressures coping with climate related adversities. International Journal of Environmental Research and Public Health, 8, 4039-54.

Beseler, C. L., \& Stallones, L. (2008). A cohort study of pesticide poisoning and depression in Colorado farm residents. Annals of Epidemiology, 18, 768-74.

Bosma, H., Schrijvers, C., \& Mackenbach, J. P. (1999). Socioeconomic inequalities in mortality and importance of perceived control: cohort study. BMJ, 319, 1469-70.

Braveman, P. A., Cubbin, C., Egerter, S., Chideya, S., Marchi, K. S., Metzler, M., \& Posner, S. (2005). Socioeconomic status in health research. JAMA: The Journal of the American Medical Association, 294, 2879-88.

Bridges, S., \& Disney, R. (2010). Debt and depression. Journal of Health Economics, 29, 388-403.

Brown, S., Taylor, K., \& Price, S. W. (2005). Debt and distress: Evaluating the psychological cost of credit. Journal of Economic Psychology, 26, 642-63. 
Butterworth, P., Olesen, S. C., \& Leach, L. S. (2012). The role of hardship in the association between socio-economic position and depression. Australia and New Zealand Journal of Psychiatry, 46, 364-73.

Butterworth, P., Rodgers, B., \& Windsor, T. D. (2009). Financial hardship, socio-economic position and depression: results from the PATH Through Life Survey. Social Science and Medicine, 69, 229-37.

Cairney, J., \& Boyle, M. H. (2004). Home ownership, mortgages and psychological distress. Housing Studies, 19, 161-74.

Caputo, R. K. (2012). Patterns and Predictors of Debt: A Panel Study, 1985-2008. Journal of sociology and social welfare, 39, 7-29.

Carney, C., McNeish, S., \& McColl, J. (2005). The impact of part time employment on students' health and academic performance: a Scottish perspective. Journal of Further and Higher Education, 29, 307-19.

Chan, S. S., Chiu, H. F., Chen, E. Y., Chan, W. S., Wong, P. W., Chan, C. L., Law, Y. W., \& Yip, P. S. (2009). Population-attributable risk of suicide conferred by axis I psychiatric diagnoses in a Hong Kong Chinese population. Psychiatric Services, 60, 1135-8.

Chen, E. Y. H., Chan, W. S. C., Wong, P. W. C., Chan, S. S. M., Chan, C. L. W., Law, Y. W., Beh, P. S. L., Chan, K. K., Cheng, J. W. Y., Liu, K. Y., \& Yip, P. S. F. (2006). Suicide in Hong Kong: a case-control psychological autopsy study. Psychological medicine, 36, 815-25.

Clark, C., Pike, C., McManus, S., Harris, J., Bebbington, P., Brugha, T., Jenkins, R., Meltzer, H., Weich, S., \& Stansfeld, S. (2012). The contribution of work and non-work stressors to common mental disorders in the 2007 Adult Psychiatric Morbidity Survey. Psychological medicine, 42, 829-42.

Cochrane. (2008). Review Manager (RevMan) (Version 5). In. Copenhagen: The Nordic Cochrane Centre, The Cochrane Collaboration.

Cooke, R., Barkham, M., Audin, K., Bradley, M., \& Davy, J. (2004). Student debt and its relation to student mental health. Journal of Further and Higher Education, 28, 5366.

Cooper, C., Bebbington, P. E., Meltzer, H., Bhugra, D., Brugha, T., Jenkins, R., Farrell, M., \& King, M. (2008). Depression and common mental disorders in lone parents: results of the 2000 National Psychiatric Morbidity Survey. Psychological medicine, 38, 33542.

Corcoran, P., \& Arensman, E. (2011). Suicide and employment status during Ireland's Celtic Tiger economy. Eur J Public Health, 21, 209-14.

Credit Action. (2013). Debt Statistics January 2013 edition. Retrieved 05/02/2013 from http://www.creditaction.org.uk/assets/PDF/statistics/2013/january-2013.pdf

Drentea, P. (2000). Age, debt and anxiety. Journal of Health Society and Behaviour, 41, 43750.

Drentea, P., \& Lavrakas, P. J. (2000). Over the limit: the association among health, race and debt. Social Science \& Medicine, 50, 517-29.

Drentea, P., \& Reynolds, J. R. (2012). Neither a Borrower Nor a Lender Be The Relative Importance of Debt and SES for Mental Health Among Older Adults. Journal of Aging and Health, 24, 673-95.

Elbogen, E. B., Johnson, S. C., Wagner, H. R., Newton, V. M., \& Beckham, J. C. (2012). Financial Well-Being and Postdeployment Adjustment Among Iraq and Afghanistan War Veterans. Military Medicine, 177, 669-75. 
Federal Reserve Bank of New York. (2013). Quarterly Report on Household Debt and Credit: May 2013. New York: Federal Reserve Bank of New York. Retrieved 14/06/2013 from www.newyorkfed.org/householdcredit/HHD_C_Report_2013Q1.xlsx

Field, E., Pande, R., Papp, J., \& Park, Y. J. (2012). Repayment Flexibility Can Reduce Financial Stress: A Randomized Control Trial with Microfinance Clients in India. Plos One, 7, e45679.

Finlay-Jones, R., \& Eckhardt, B. (1984). A social and psychiatric survey of unemployment among young people. Australian and New Zealand Journal of Psychiatry, 18, 135-43.

Fitch, C. (2006). Final Demand: Debt and Mental Health. Debt and Arrears: What Service Users Want Health Workers to Know and Do. London: Royal College of Psychiatrists' Research and Training Unit.

Fitch, C., Hamilton, S., Bassett, P., \& Davey, R. (2011). The relationship between personal debt and mental health: a systematic review. Mental Health Review Journal, 16, 15366.

Gathergood, J. (2012). Debt and Depression: Causal Links and Social Norm Effects. Economic Journal, 122, 1094-114.

Goldberg, G. W., P. S. (1991). A user's guide to the General Health Questionnaire. Windsor: Basingstoke Press.

Hainer, B. L., \& Palesch, Y. (1998). Symptoms of depression in residents: a South Carolina Family Practice Research Consortium study. Academic Medicine: Journal Of The Association Of American Medical Colleges, 73, 1305-10.

Hatcher, S. (1994). Debt and Deliberate Self-Poisoning. British Journal of Psychiatry, 164, 111-14.

Hawton, K., Harriss, L., Hodder, K., Simkin, S., \& Gunnell, D. (2001). The influence of the economic and social environment on deliberate self-harm and suicide: an ecological and person-based study. Psychological Medicine, 31, 827-36.

Heimo Viinamäki, J. H., Osmo Kontula, Leo Niskanen, Kaj Koskela. (2000). Mental health at population level during an economic recession in Finland. Nordic Journal of Psychiatry, 54, 177-82.

Hintikka, J., Kontula, O., Saarinen, P., Tanskanen, A., Koskela, K., \& Viinamaki, H. (1998). Debt and suicidal behaviour in the Finnish general population. Acta Psychiatria Scandanavia, 98, 493-6.

Hope, S., Power, C., \& Rodgers, B. (1999). Does financial hardship account for elevated psychological distress in lone mothers? Social Science \& Medicine, 49, 1637-49.

Husain, N., Creed, F., \& Tomenson, B. (2000). Depression and social stress in Pakistan. Psychological medicine, 30, 395-402.

Jenkins, R., Bebbington, P., Brugha, T., Bhugra, D., Farrell, M., Coid, J., Singleton, N., \& Meltzer, H. (2009). Mental Disorder in People with Debt in the General Population. Public Health Medicine, 6, 88-92.

Jenkins, R., Bhugra, D., Bebbington, P., Brugha, T., Farrell, M., Coid, J., Fryers, T., Weich, S., Singleton, N., \& Meltzer, H. (2008). Debt, income and mental disorder in the general population. Psychological medicine, 38, 1485-93.

Jenkins, R., Fitch, C., Hurlston, M., \& Walker, F. (2009). Recession, debt and mental health: challenges and solutions. Mental Health and Family Medicine, 6, 85-90.

Jessop, D. C., Herberts, C., \& Solomon, L. (2005). The impact of financial circumstances on student health. British Journal of Health Psychology, 10, 421-39.

Kaji, T., Mishima, K., Kitamura, S., Enomoto, M., Nagase, Y., Li, L., Kaneita, Y., Ohida, T., Nishikawa, T., \& Uchiyama, M. (2010). Relationship between late-life depression and 
life stressors: Large-scale cross-sectional study of a representative sample of the Japanese general population. Psychiatry and Clinical Neurosciences, 64, 426-34.

Kassim, S., \& Croucher, R. (2006). Khat chewing amongst UK resident male Yemeni adults: an exploratory study. International Dental Journal, 56, 97-101.

Keese, M., \& Schmitz, H. (2012). Broke, Ill, and Obese: Is There an Effect of Household Debt on Health? Review of Income and Wealth. Epub ahead of print, doi: 10.1111/roiw.12002

Kendzor, D. E., Businelle, M. S., Costello, T. J., Castro, Y., Reitzel, L. R., Cofta-Woerpel, L. M., Li, Y., Mazas, C. A., Vidrine, J. I., Cinciripini, P. M., Greisinger, A. J., \& Wetter, D. W. (2010). Financial Strain and Smoking Cessation Among Racially/Ethnically Diverse Smokers. American Journal of Public Health, 100, 702-06.

Koppel, S., \& McGuffin, P. (1999). Socio-economic factors that predict psychiatric admissions at a local level. Psychological medicine, 29, 1235-41.

Laaksonen, E., Martikainen, P., Lahelma, E., Lallukka, T., Rahkonen, O., Head, J., \& Marmot, M. (2007). Socioeconomic circumstances and common mental disorders among Finnish and British public sector employees: evidence from the Helsinki Health Study and the Whitehall II Study. International Journal of Epidemiology, 36, 776-86.

Laaksonen, E., Martikainen, P., Lallukka, T., Lahelma, E., Ferrie, J., Rahkonen, O., Marmot, M., \& Head, J. (2009). Economic difficulties and common mental disorders among Finnish and British white-collar employees: the contribution of social and behavioural factors. Journal of epidemiology and community health, 63, 439-46.

Laaksonen, M., Rahkonen, O., Martikainen, P., \& Lahelma, E. (2005). Socioeconomic position and self-rated health: the contribution of childhood socioeconomic circumstances, adult socioeconomic status, and material resources. American Journal of Public Health, 95.

Lahelma, E., Laaksonen, M., Martikainen, P., Rahkonen, O., \& Sarlio-Lähteenkorva, S. (2006). Multiple measures of socioeconomic circumstances and common mental disorders. Social science \& medicine (1982), 63, 1383.

Lange, C., \& Byrd, M. (1998). The relationship between perceptions of financial distress and feelings of psychological well-being in New Zealand university students. International Journal of Adolescence and Youth, 7, 193-209.

Lee, Y. G., \& Brown, S. (2007). Financial Distress and Depressive Symptoms: How Do Older Women and Men Differ? Hallym International Journal of Aging, 9, 125-44.

Lee, Y. G., Lown, J. M., \& Sharpe, D. L. (2007). Predictors of holding consumer and mortgage debt among older Americans. Journal of Family and Economic Issues, 28, 305-20.

Lewis, G., Pelosi, A. J., Araya, R., \& Dunn, G. (1992). Measuring psychiatric disorder in the community: a standardized assessment for use by lay interviewers. Psychological medicine, 22, 465-86.

Lorant, V., Deliege, D., Eaton, W., Robert, A., Philippot, P., \& Ansseau, M. (2003). Socioeconomic inequalities in depression: a meta-analysis. American Journal of Epidemiology, 157, 98-112.

Lorant, V., Kunst, A. E., Huisman, M., Costa, G., \& Mackenbach, J. (2005). Socio-economic inequalities in suicide: a European comparative study. The British Journal of Psychiatry, 187, 49-54.

Lyons, A. C., \& Yilmazer, T. (2005). Health and financial strain: Evidence from the survey of consumer finances. Southern Economic Journal, 71, 873-90. 
Maccallum, F., \& Blaszczynski, A. (2003). Pathological gambling and suicidality: An analysis of severity and lethality. Suicide and life-threatening behavior, 33, 88-98.

Mackenbach, J. P., Stirbu, I., Roskam, A. J. R., Schaap, M. M., Menvielle, G., Leinsalu, M., $\&$ Kunst, A. E. (2008). Socioeconomic inequalities in health in 22 European countries. New England Journal of Medicine, 358, 2468-81.

Meltzer, H., Bebbington, P., Brugha, T., Farrell, M., \& Jenkins, R. (2013). The relationship between personal debt and specific common mental disorders. European Journal of Public Health, 23, 108-13.

Meltzer, H., Bebbington, P., Brugha, T., Jenkins, R., McManus, S., \& Dennis, M. S. (2011). Personal debt and suicidal ideation. Psychological medicine, 41, 771-8.

Meltzer, H., Bebbington, P., Brugha, T., Jenkins, R., McManus, S., \& Stansfeld, S. (2010). Job insecurity, socio-economic circumstances and depression. Psychological medicine, 40, 1401-07.

Molander, R. C., Yonker, J. A., \& Krahn, D. D. (2010). Age-related changes in drinking patterns from mid- to older age: results from the Wisconsin longitudinal study. Alcoholism, Clinical And Experimental Research, 34, 1182-92.

Munster, E., Ruger, H., Ochsmann, E., Letzel, S., \& Toschke, A. (2009). Over-indebtedness as a marker of socioeconomic status and its association with obesity: a cross-sectional study. BMC Public Health, 9, 286.

Nelson, M. C., Lust, K., Story, M., \& Ehlinger, E. (2008). Credit card debt, stress and key health risk behaviors among college students. American Journal of Health Promotion, 22, 400-07.

Norvilitis, J. M., Szablicki, P. B., \& Wilson, S. D. (2003). Factors Influencing Levels of Credit-Card Debt in College Students. Journal of Applied Social Psychology, 33, 93547.

O’Neill, B., Sorhaindo, B., Xiao, J. J., \& Garman, E. T. (2005). Financially distressed consumers: Their financial practices, financial well-being, and health. Financial Counseling and Planning, 16, 73-87.

Ochsmann, E. B., Rueger, H., Letzel, S., Drexler, H., \& Muenster, E. (2009). Overindebtedness and its association with the prevalence of back pain. BMC Public Health, 9, 451-51.

Patel, V., Kirkwood, B. R., Weiss, H., Pednekar, S., Fernandes, J., Pereira, B., Upadhye, M., \& Mabey, D. (2005). Chronic fatigue in developing countries: population based survey of women in India. British Medical Journal, 330, 1190.

Patel, V., Pereira, J., Coutinho, L., Fernandes, R., Fernandes, J., \& Mann, A. (1998). Poverty, psychological disorder and disability in primary care attenders in Goa, India. The British Journal of Psychiatry, 172, 533-36.

Pleasence, P., \& Balmer, N. J. (2007). Changing Fortunes: Results from a Randomized Trial of the Offer of Debt Advice in England and Wales. Journal of Empirical Legal Studies, 4, 651-73.

Pollack, C. E., Chideya, S., Cubbin, C., Williams, B., Dekker, M., \& Braveman, P. (2007). Should health studies measure wealth? A systematic review. American Journal of Preventive Medicine, 33, 250.

Polprasert, W., Sawangdee, Y., Porrapakham, Y., Guo, G., \& Sirirassamee, B. (2006). Influences of socio-demographic and social context risk factors on labor force aged mortality from communicable disease. Journal of The Medical Association of Thailand $=$ Chotmaihet Thangphaet, 89, 854-63. 
Pothen, M., Kuruvilla, A., Philip, K., Joseph, A., \& Jacob, K. (2003). Common mental disorders among primary care attenders in Vellore, South India: nature, prevalence and risk factors. International Journal of Social Psychiatry, 49, 119-25.

Qin, P., Agerbo, E., \& Mortensen, P. B. (2003). Suicide risk in relation to socioeconomic, demographic, psychiatric, and familial factors: A national register-based study of all suicides in Denmark, 1981-1997. American Journal of Psychiatry, 160, 765-72.

Radloff, L. S. (1977). The CES-D scale A self-report depression scale for research in the general population. Applied psychological measurement, 1, 385-401.

Reading, R., \& Reynolds, S. (2001). Debt, social disadvantage and maternal depression. Social Science \& Medicine, 53, 441-53.

Roberts, R., Golding, J., Towell, T., Reid, S., Woodford, S., Vetere, A., \& Weinreb, I. (2000). Mental and physical health in students: The role of economic circumstances. British Journal of Health Psychology, 5, 289-97.

Roberts, R., Golding, J., Towell, T., \& Weinreb, I. (1999). The effects of economic circumstances on British students' mental and physical health. Journal of American College Health, 48, 103-09.

Ross, S., Cleland, J., \& Macleod, M. J. (2006). Stress, debt and undergraduate medical student performance. Medical education, 40, 584-89.

Saxena, S., Sharma, R., \& Maulik, P. K. (2003). Impact of alcohol use on poor families: a study from North India. Journal of Substance Use, 8, 78-84.

Scott, K. M., Von Korff, M., Alonso, J., Angermeyer, M. C., Bromet, E., Fayyad, J., de Girolamo, G., Demyttenaere, K., Gasquet, I., Gureje, O., Haro, J. M., He, Y., Kessler, R. C., Levinson, D., Medina Mora, M. E., Oakley Browne, M., Ormel, J., PosadaVilla, J., Watanabe, M., \& Williams, D. (2009). Mental-physical co-morbidity and its relationship with disability: results from the World Mental Health Surveys. Psychological medicine, 39, 33-43.

Selenko, E., \& Batinic, B. (2011). Beyond debt. A moderator analysis of the relationship between perceived financial strain and mental health. Social Science \& Medicine.

Shavers, V. L. (2007). Measurement of socioeconomic status in health disparities research. Journal of the National Medical Association, 99, 1013.

Stuhldreher, W. L., Stuhldreher, T. J., \& Forrest, K. Y. Z. (2007). Gambling as an emerging health problem on campus. Journal of American College Health, 56, 75-88.

Swanson, S. A., Crow, S. J., Le Grange, D., Swendsen, J., \& Merikangas, K. R. (2011). Prevalence and correlates of eating disorders in adolescents. Results from the national comorbidity survey replication adolescent supplement. Archices of General Psychiatry, 68, 714-23.

Taylor, M. P., Pevalin, D. J., \& Todd, J. (2007). The psychological costs of unsustainable housing commitments. Psychological medicine, 37, 1027-36.

Turvey, C., Stromquist, A., Kelly, K., Zwerling, C., \& Merchant, J. (2002). Financial loss and suicidal ideation in a rural community sample. Acta Psychiatria Scandanavia, 106, 373-80.

Wagmiller, R. L. (2003). Debt and assets among low-income families. New York: National Center for Children in Poverty, Columbia University. Retreived 05/02/2013 from http://academiccommons.columbia.edu/catalog/ac:127512

Wahlbeck, K., \& McDaid, D. (2012). Actions to alleviate the mental health impact of the economic crisis. World Psychiatry, 11, 139-45.

Wang, J. L., Schmitz, N., \& Dewa, C. S. (2010). Socioeconomic status and the risk of major depression: the Canadian National Population Health Survey. Journal of Epidemiology and Community Health, 64, 447-52. 
Ware, J. E., Snow, K.K., Kosinski, M. \& Gandek, B. (1993). SF-36 Health Survey: Manual and Interpretation Guide. Boston: The Health Institute, New England Medical Center.

Webley, P., \& Nyhus, E. K. (2001). Life-cycle and dispositional routes into problem debt. British Journal of Psychology, 92, 423-46.

Wong, P. W., Chan, W. S., Conwell, Y., Conner, K. R., \& Yip, P. S. (2010). A psychological autopsy study of pathological gamblers who died by suicide. Journal of Affective Disorders, 120, 213-6.

Wong, P. W. C., Chan, W. S. C., Chen, E. Y. H., Chan, S. S. M., Law, Y. W., \& Yip, P. S. F. (2008). Suicide among adults aged 30-49: A psychological autopsy study in Hong Kong. BMC Public Health, 8, 147-47.

$\mathrm{Xu}, \mathrm{Y}$. (2011). Ethnic Variations in the Relationship Between Socioeconomic Status and Psychological Distress Among Latino Adults. Race and Social Problems, 3, 212-24.

Yao, R., Sharpe, D. L., \& Gorham, E. E. (2011). An Exploratory Study of Chinese Americans' Debt Ownership. Journal of family and economic issues, 32, 600-11.

Zimmerman, F. J., \& Katon, W. (2005). Socioeconomic status, depression disparities, and financial strain: what lies behind the income-depression relationship? Health Economics, 14, 1197-215. 


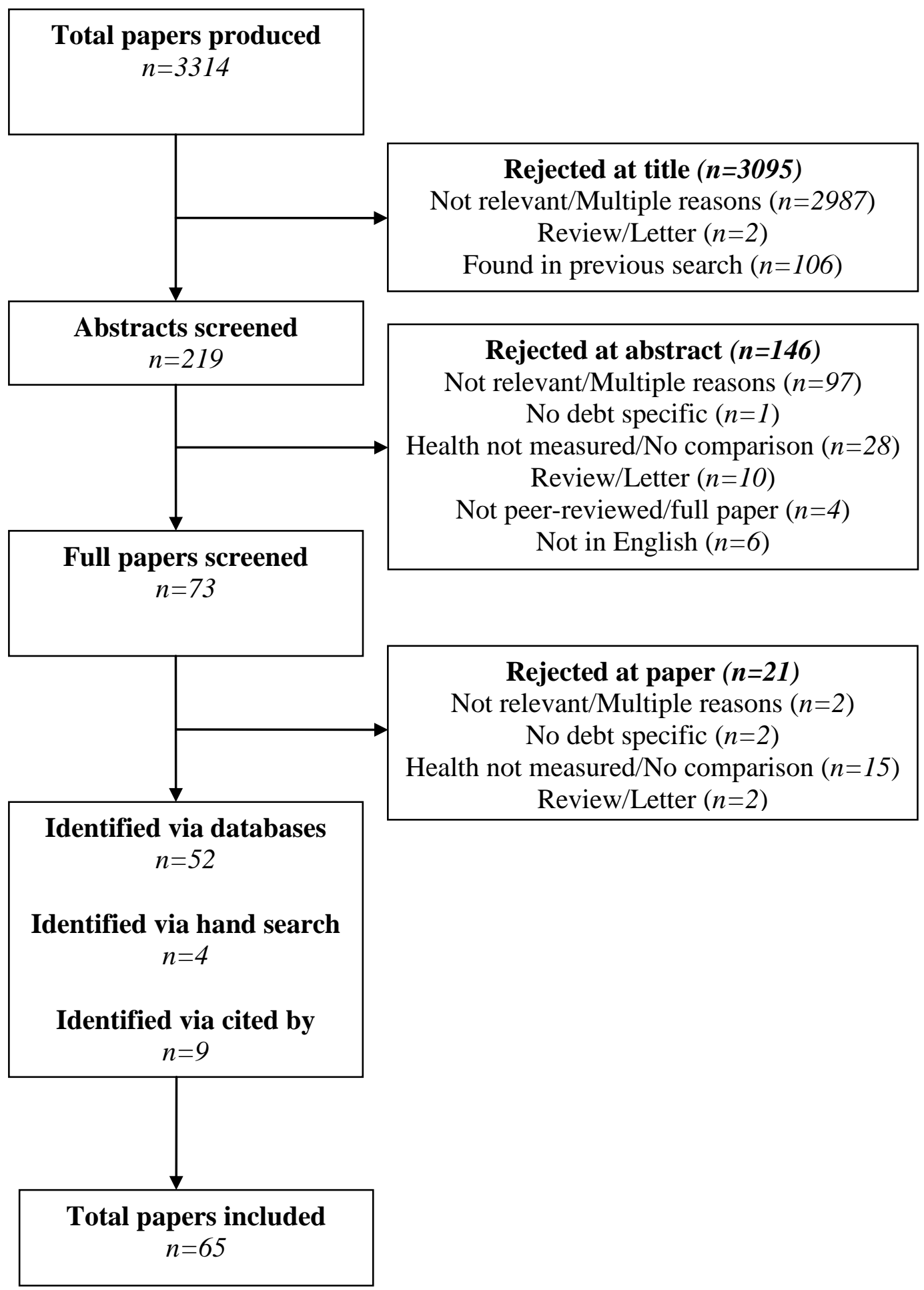

Figure 1: Flow Diagram of Systematic Search 
Table 1

Results of the Meta Analysis

\begin{tabular}{|c|c|c|c|c|c|c|}
\hline Variable & Studies & $\begin{array}{l}\text { Total Pooled } \\
\text { Sample Size }\end{array}$ & Heterogeneity & Prevalence/Proportions & $\begin{array}{l}\text { Odds Ratio* } \\
(95 \% \text { CI })\end{array}$ & Overall Effect \\
\hline Mental Disorder & $\mathrm{n}=7^{2}$ & 33961 & $\chi 2=11.14, p>.05$ & $\begin{array}{c}\text { Prevalence of Mental Disorder in: } \\
\text { - Debt: } 41.9 \%(1754 / 4178) \\
\text { - No Debt: } 17.5 \%(5212 / 29783) \\
\text { Prevalence of Debt in: } \\
\text { - Mental Disorder: } 25.2 \%(1754 / 6966) \\
\text { - No Mental Disorder: } 8.9 \%(2424 / 26995)\end{array}$ & $3.24(2.91,3.60)$ & $\mathrm{Z}=21.68, \mathrm{p}<.001$ \\
\hline Depression & $n=4^{3}$ & 33987 & $\chi 2=1.14, p>.05$ & $\begin{array}{c}\text { Prevalence of Depression in: } \\
\text { - Debt: } 15.5 \%(691 / 4458) \\
\text { - No Debt: } 13.2 \%(3903 / 29529) \\
\text { Prevalence of Debt in: } \\
\text { - Depression: } 15 \%(691 / 4594) \\
\text { - No Depression: } 12.8 \%(4595 / 29393)\end{array}$ & $2.77(2.5,3.07)$ & $\mathrm{Z}=19.45, \mathrm{p}<.001$ \\
\hline $\begin{array}{c}\text { Suicide } \\
\text { completion* }\end{array}$ & $\mathrm{n}=4^{4}$ & 1069 & $\chi^{2}=0.10, p>.05$ & $\begin{array}{c}\text { Prevalence of Debt in: } \\
\text { - Suicide Completers: } 31 \%(166 / 535) \\
\text { - Controls: } 5.4 \%(29 / 534)\end{array}$ & $7.9(5.21,12.0)$ & $\mathrm{Z}=9.71, \mathrm{p}<.001$ \\
\hline Suicide completion & $\mathrm{n}=5^{5}$ & 5822 & $\chi 2=14.31, p<.01$ & Prevalence of Debt in: & $5.76(2.97$ & $\mathrm{Z}=5.17, \mathrm{p}<.001$ \\
\hline
\end{tabular}


DEBT AND HEALTH

or attempt*

Smoking

$$
n=3^{6}
$$

11801

$\chi^{2}=33.96, p<.001$

Problem Drinking

$$
\mathrm{n}=5^{7}
$$

26706

$$
\chi 2=162.48
$$$$
\mathrm{p}<.001
$$

Drug Dependence

$$
n=2^{8}
$$

15281

$$
\chi 2=5.01, \mathrm{p}<.05
$$

Neurotic Disorders

$$
\mathrm{n}=2^{9}
$$

16521

$$
\chi 2=3.46, p>.05
$$

- Suicide Completers/Attempters: 30.9\%

$$
(181 / 584)
$$

- Controls: 17.2\% (903/5239)

Prevalence of Smoking in:

- Debt: $28.8 \%$ (1088/3778)

- No Debt: 20.6\% (1650/8023)

Prevalence of Debt in:

- Smokers: $39.7 \%$ (1088/2738)

- Non-smokers: $29.7 \%$ (2690/9063)

Prevalence of Problem Drinking in:

- Debt: 32.2\% (1669/5162)

- No Debt: 18\% (3878/21544)

Prevalence of Debt in:

- Problem Drinking: 30.1\% (1669/5547)

- No Problem Drinking: 16.5\% (3493/21159)

Prevalence of Drug dependence in:

- Debt: $12.9 \%$ (222/1712)

- No Debt: 2.6\% (258/13569)

Prevalence of Debt in:

- Drug Dependence: 38.3\% (222/580)

- No Drug Dependence: 10.1\% (1490/14701)

Prevalence of Neurotic Disorders in: - Debt: 36\% (710/1971)
11.18)

$1.35(0.66,2.77)$

$\mathrm{Z}=0.83, \mathrm{p}>.05$

$2.68(1.40,5.15)$

$\mathrm{Z}=2.96, \mathrm{p}<.01$

$5.69(3.82,8.47)$

$\mathrm{Z}=8.57, \mathrm{p}<.001$

$3.21(2.64,3.90)$

$\mathrm{Z}=11.63, \mathrm{p}<.001$ 
DEBT AND HEALTH

Panic, Phobia,

GAD)

Psychotic

Disorders $\mathrm{n}=2^{9}$

15083
- No Debt: 15.1\% (2197/14550)

Prevalence of Debt in:

- Neurotic Disorders: 24.4\% (710/2907)

- No Neurotic Disorders: 9.3\% (1261/13614)

Prevalence of Psychotic Disorders in:

$4.03[2.64,6.16]$

$\mathrm{Z}=6.46, \mathrm{p}<.001$

- No Debt: 0.5\% (71/13453)

Prevalence of Debt in:

- Psychotic Disorders: $31.1 \%$ (32/103)

- No Psychotic Disorders: 10.7\% (1598/14980)

Mantel-Haenszel random effect model weighted by sample size 95\% CI.

* Pooled unadjusted odds ratio

* The prevalence of suicide completion in those with debt is not given as due to equal numbers of completers and controls this estimate would be inflated.

${ }^{1}$ Clark et al., 2012; Finlay-Jones \& Eckhardt, 1984; Hintikka et al., 2008; Jenkins et al., 2008; Jenkins et al., 2009; Meltzer et al., 2013; Patel et al., 1998.

${ }^{2}$ Besler \& Stallones, 2008; Bridges \& Disney, 2010; Kaji et al., 2010; Stuhldreher et al., 2007

${ }^{3}$ Chan et al., 2009; Chen et al., 2006; Wong et al., 2008; Wong et al., 2010.

${ }^{4}$ Chan et al., 2009; Chen et al., 2006; Hintikka et al., 2008; Wong et al., 2008; Wong et al., 2010.

${ }^{5}$ Berg et al., 2010; Drentea \& Lavrakas, 2000; Stuhldreher et al., 2007.

${ }^{6}$ Berg et al., 2010; Jenkins et al., 2008; Jenkins et al., 2009; Saxena et al., 2007; Stuhldreher et al., 2007.

${ }^{7}$ Jenkins et al., 2008; Jenkins et al., 2009.

${ }^{8}$ Jenkins et al., 2008; Jenkins et al., 2009.

${ }^{9}$ Jenkins et al., 2008; Jenkins et al., 2009. 
Appendix A

Characteristics of studies with University Students

\begin{tabular}{|c|c|c|c|c|}
\hline Study & Country & Design & Sample & Measures Used \\
\hline $\begin{array}{l}\text { Adams \& } \\
\text { Moore } \\
(2007)\end{array}$ & US & $\begin{array}{l}\text { Cross- } \\
\text { sectional }\end{array}$ & $\begin{array}{l}40,209 \\
\text { students }\end{array}$ & ACQ on finances and healtl \\
\hline $\begin{array}{l}\text { Berg et al. } \\
(2010)\end{array}$ & US & $\begin{array}{l}\text { Cross- } \\
\text { sectional }\end{array}$ & $\begin{array}{l}9931 \\
\text { students }\end{array}$ & ACQ on finances and healtl \\
\hline $\begin{array}{l}\text { Carney et al. } \\
(2005) \\
\text { Cooke et al. } \\
(2004)\end{array}$ & $\begin{array}{l}\text { UK } \\
\text { UK }\end{array}$ & $\begin{array}{l}\text { Cross- } \\
\text { sectional } \\
\text { Longitudinal } \\
\text { (3 years) }\end{array}$ & $\begin{array}{l}756 \\
\text { students } \\
2146 \\
\text { students }\end{array}$ & $\begin{array}{l}\text { - ACQ on finances } \\
\text { - SF-36 } \\
\text { - CORE-GP } \\
\text { - ACQ on debt }\end{array}$ \\
\hline $\begin{array}{l}\text { Jessop et al. } \\
(2005)\end{array}$ & $\begin{array}{l}\text { - UK } \\
\text { - Finland }\end{array}$ & $\begin{array}{l}\text { - Cross- } \\
\text { sectional } \\
\text { - Cohort } \\
\text { study }\end{array}$ & $\begin{array}{l}\text { - } 89 \text { British } \\
\text { students } \\
\text { - } 98 \text { Finnish } \\
\text { students }\end{array}$ & $\begin{array}{l}\text { - Questions on finances } \\
\text { from Roberts et al (2000) } \\
\text { - SF-36 }\end{array}$ \\
\hline
\end{tabular}

Main findings

- Higher BMI

- Used amphetamines past 30 days

- Felt impaired by depression in past year

- Not using cannabis

Those in debt more likely to have:

- Smoked and drunk alcohol past 30 days

- High risk drinking past two weeks

- More days of poor MH

Effects for smoking and MH greater for

greater debt

- Indebtedness related to lower scores on

physical and mental health.

- No correlation between debt and CORE-GP - None

- Higher CORE-GP scores for those with high debt worry

- Correlation between financial concern and CORE-GP

- Those with high financial concern had greater increase in symptoms over time

British students (more debt than Finnish students) had:

- Higher scores on all but one SF-36 subscale
Confounds controlled

- Age, year in

university,

international

- Age, gender, type

of university

\section{- None}

- Gender, age, hours worked, smoking and alcohol use 


\begin{tabular}{|c|c|c|c|c|c|c|}
\hline Study & Country & Design & Sample & Measures Used & Main findings & Confounds controlled \\
\hline $\begin{array}{l}\text { Lange \& } \\
\text { Byrd (1998) }\end{array}$ & $\begin{array}{l}\text { New } \\
\text { Zealand }\end{array}$ & $\begin{array}{l}\text { - Cross- } \\
\text { sectional } \\
\text { - Path } \\
\text { Analysis }\end{array}$ & 237 students & $\begin{array}{l}\text { - ACQ on demographics and } \\
\text { Finances } \\
\text { - Economic Locus of } \\
\text { - Self-esteem Inventory } \\
\text { - Hopkins Symptoms } \\
\text { Checklist }\end{array}$ & $\begin{array}{l}\text { - More likely to smoke (55\% vs 12\%), and } \\
\text { smoked more } \\
\text { - No difference on number drinks per week } \\
\text { Financial concern mediated relationship } \\
\text { between amount of debt and SF-36 score } \\
\text { Path analysis, two paths found: } \\
\text { - Current debt leads to daily financial stress, } \\
\text { then manageability, internal Locus of } \\
\text { Control, then anxiety and depression } \\
\text { - Current debt related to estimated future } \\
\text { chronic financial strain, to } \\
\text { comprehensibility, which effects Locus of } \\
\text { Control and self-esteem, leading to anxiety } \\
\text { and depression }\end{array}$ & - None \\
\hline $\begin{array}{l}\text { Nelson et al. } \\
(2008)\end{array}$ & US & $\begin{array}{l}\text { Cross- } \\
\text { sectional }\end{array}$ & $\begin{array}{l}3206 \\
\text { students }\end{array}$ & $\begin{array}{l}\text { - ACQ on finances and } \\
\text { health }\end{array}$ & $\begin{array}{l}\text { Those with credit card debt more likely to: } \\
\text { - Report body dissatisfaction } \\
\text { - Binge drink } \\
\text { - Have used tobacco and cannabis past month } \\
\text { - Have used other drugs past year }\end{array}$ & $\begin{array}{l}\text { - Gender, age, } \\
\text { ethnicity, hours } \\
\text { Worked }\end{array}$ \\
\hline $\begin{array}{l}\text { Norvilitis et } \\
\text { al. (2003) }\end{array}$ & US & $\begin{array}{l}\text { Cross- } \\
\text { sectional }\end{array}$ & 227 students & $\begin{array}{l}\text { - ACQ on demographics and } \\
\text { - Student Financial Well } \\
\text { Being Scale } \\
\text { - Measure of student } \\
\text { towards debt } \\
\text { - Stress subscale of } \\
\text { depression anxiety scale }\end{array}$ & $\begin{array}{l}\text { - Financial well-being correlated with stress } \\
\text { - Stress not related to debt-to-income ratio } \\
\text { or attitudes towards debt }\end{array}$ & - None \\
\hline
\end{tabular}




\begin{tabular}{|c|c|c|c|c|c|c|}
\hline Study & Country & Design & Sample & Measures Used & Main findings & Confounds controlled \\
\hline $\begin{array}{l}\text { Norvilitis et } \\
\text { al. (2006) }\end{array}$ & US & $\begin{array}{l}\text { Cross- } \\
\text { sectional }\end{array}$ & 448 students & $\begin{array}{l}\text { - As per Norvilitis } 2003 \\
\text { paper }\end{array}$ & - Higher levels of debt related to more stress & - None \\
\hline $\begin{array}{l}\text { Roberts et al. } \\
\text { (1999) }\end{array}$ & England & $\begin{array}{l}\text { Cross- } \\
\text { sectional }\end{array}$ & 360 students & $\begin{array}{l}\text { - ACQ on demographics, } \\
\text { smoking, drug and alcohol } \\
\text { use } \\
\text { - SF-36 } \\
\text { - GHQ-12 } \\
\text { - Measure of } 14 \text { physical } \\
\text { symptoms }\end{array}$ & $\begin{array}{l}\text { - Difficulty paying bills predict higher } \\
\text { GHQ } \\
\text { - Those who considered dropping out for } \\
\text { financial reasons: } \\
\text { - Worse physical health on SF-36, more } \\
\text { likely to smoke, higher GHQ } \\
\text { SEM found two paths: } \\
\text { - As amount of debt increases, likelihood of } \\
\text { consider abandoning studies increases, } \\
\text { which then worsens MH } \\
\text { - As both debt and consider abandon studies } \\
\text { increase, longer hours worked, which then } \\
\text { worsens MH }\end{array}$ & $\begin{array}{l}\text { - Age and Gender } \\
\text { - Smoking (for } \\
\text { physical health } \\
\text { analyses) }\end{array}$ \\
\hline $\begin{array}{l}\text { Roberts et al. } \\
(2000)\end{array}$ & UK & $\begin{array}{l}\text { Cross- } \\
\text { Sectional }\end{array}$ & 482 students & - As per Roberts 1999 paper & $\begin{array}{l}\text { - Difficulty paying bills predict higher } \\
\text { GHQ } \\
\text { - Those who considered dropping out for } \\
\text { financial reasons: } \\
\text { - Higher score on GHQ and all SF-36 } \\
\text { subscales } \\
\text { - Smoked more, more drug use } \\
\text { SEM found same path as Roberts } 1999\end{array}$ & $\begin{array}{l}\text { - Age and Gender } \\
\text { - Smoking (for } \\
\text { physical health } \\
\text { analyses) }\end{array}$ \\
\hline $\begin{array}{l}\text { Ross et al. } \\
(2006)\end{array}$ & Scotland & $\begin{array}{l}\text { Cross- } \\
\text { sectional }\end{array}$ & $\begin{array}{l}334 \text { medical } \\
\text { students }\end{array}$ & $\begin{array}{l}\text { - ACQ on demographics, } \\
\text { smoking and alcohol use } \\
\text {-GHQ-12 }\end{array}$ & $\begin{array}{l}\text { - No relationship between money worry and } \\
\text { binge drinking- Those above cut-off on GHQ } \\
\text { - Those above cut-off on GHQ had lower } \\
\text { debts }\end{array}$ & - Year of study \\
\hline
\end{tabular}




\begin{tabular}{l|lllll}
\multicolumn{1}{c|}{ Study } & Country & Design & Sample & Measures Used & Main findings \\
\hline $\begin{array}{l}\text { Stuhldreher } \\
\text { et al. (2007) }\end{array}$ & US & Cross- & 1079 students & - Questions from previous & Those with past gambling-related debt more \\
& & sectional & students & $\begin{array}{l}\text { study on health, alcohol } \\
\text { and drug use }\end{array}$ & likely to: \\
& & & - BDI & - Binge drink, currently smoke, have used \\
& & & - ACQ on gambling & - Score above cut-off for depression of BDI \\
& & & & behaviour & - Report their general stress was too high \\
\hline
\end{tabular}

Abbreviations: $\mathrm{ACQ}=$ Author Constructed Questions, $\mathrm{SF}=$ Short Form Health Survey, CORE-GP=Clinical Outcomes Routine Evaluation General Population version, $\mathrm{MH}=$ Mental Health, $\mathrm{GHQ}=$ General Health Questionnaire, SEM=Structural Equation Modelling, BDI=Beck Depression Inventory. 


\begin{tabular}{|c|c|c|c|c|c|c|}
\hline \multirow[b]{2}{*}{ Study } & \multicolumn{3}{|c|}{ - 18 years } & \multirow[b]{2}{*}{ Measures Used } & \multirow[b]{2}{*}{ Main findings } & \multirow{2}{*}{$\begin{array}{l}\text { problems. } \\
\text { Confounds Controlled }\end{array}$} \\
\hline & Country & Design & Sample & & & \\
\hline $\begin{array}{l}\text { Keese \& Schmitz } \\
\text { (2012) }\end{array}$ & Germany & $\begin{array}{l}\text { - Panel survey } \\
\text { - } 10 \text { years } \\
\text { - } 6 \text { time points }\end{array}$ & $\begin{array}{l}\text { - } 32,132 \\
\text { general pop. }\end{array}$ & $\begin{array}{l}\text { - ACQ on finances } \\
\text { - Health satisfaction } \\
\text { point scale } \\
\text { - MH score based } \\
\text { - BMI }\end{array}$ & $\begin{array}{l}\text { - Debt-to-income sig predicted health } \\
\text { satisfaction and MH score } \\
\text { - No effect on obesity } \\
\text { - Indebtedness related to health satisfaction } \\
\text { only in those with variable employment } \\
\text { - Results similar when ran for household } \\
\text { heads only }\end{array}$ & $\begin{array}{l}\text { - Demographics, employment, } \\
\text { health insurance, income, } \\
\text { recent death or separation }\end{array}$ \\
\hline $\begin{array}{l}\text { Webley \& Nyhus } \\
\text { (2001) }\end{array}$ & $\begin{array}{l}\text { Netherl- } \\
\text { ands }\end{array}$ & $\begin{array}{l}\text { - Panel survey } \\
-3 \text { years } \\
\text { - } 3 \text { time points }\end{array}$ & $\begin{array}{l}\text { - } 4147 \\
\text { general pop. }\end{array}$ & $\begin{array}{l}\text { - ACQ on health, } \\
\text { finances, } \\
\text { demographics, } \\
\text { smoking, alcohol } \\
\text { - BMI }\end{array}$ & $\begin{array}{l}\text { - Those with debt more likely to smoke, } \\
\text { smoke more and drink more } \\
\text { - Obesity predicted debt status }\end{array}$ & $\begin{array}{l}\text { - None } \\
\text { - Income, age, number children } \\
\text { partner present, attitude to } \\
\text { debt, money management, } \\
\text { impulsive spending }\end{array}$ \\
\hline
\end{tabular}

Abbreviations: $\mathrm{ACQ}=$ Author Constructed Questions, pop.=population, $\mathrm{MH}=$ Mental Health, $\mathrm{GHQ}=\mathrm{General} \mathrm{Health} \mathrm{Questionnaire,} \mathrm{BMI}=\mathrm{Body}$

Mass Index. 
Appendix C

Characteristics of Psychological Autopsy Studies

\begin{tabular}{|c|c|c|c|c|c|c|}
\hline Study & Country & Design & Sample & Measures Used & Main findings & Confounds controlled \\
\hline $\begin{array}{l}\text { Chan et al. } \\
(2009)\end{array}$ & $\begin{array}{l}\text { China } \\
\text { (Hong } \\
\text { Kong) }\end{array}$ & $\begin{array}{l}\text { - Psychological } \\
\text { autopsy } \\
\text { - Case } \\
\text { controlled }\end{array}$ & $\begin{array}{l}\text { - } 150 \text { suicide completers } \\
\text { - } 150 \text { community controls }\end{array}$ & $\begin{array}{l}\text { - Interviews with } \\
\text { relatives of } \\
\text { completers } \\
\text { - SCID } \\
\text { - Information from } \\
\text { coroner's report }\end{array}$ & $\begin{array}{l}\text { - Greater prevalence of } \\
\text { unmanageable debt in completers } \\
\text { aOR of } 9.5 \\
\text { - Population attributable risk of } \\
\text { unmanageable debt }=23 \%\end{array}$ & $\begin{array}{l}\text { - Psychiatric diagnosis, } \\
\text { substance use disorder, } \\
\text { pathological gambling, } \\
\text { past suicide attempts, } \\
\text { unemployment }\end{array}$ \\
\hline $\begin{array}{l}\text { Chen et al. } \\
(2006)\end{array}$ & $\begin{array}{l}\text { China } \\
\text { (Hong } \\
\text { Kong) }\end{array}$ & $\begin{array}{l}\text { - Psychological } \\
\text { autopsy } \\
\text { - Case } \\
\text { controlled }\end{array}$ & $\begin{array}{l}\text { - } 150 \text { suicide completers } \\
\text { - } 150 \text { community controls }\end{array}$ & $\begin{array}{l}\text { - Interviews with } \\
\text { relatives of } \\
\text { completers }\end{array}$ & $\begin{array}{l}\text { - Greater prevalence of } \\
\text { unmanageable debt in completers } \\
\text { aOR of } 7.9 \\
\text { - Effect remained after excluding } \\
\text { pathological gamblers and } \\
\text { compulsive buyers } \\
\text { - No interaction between effect of } \\
\text { diagnosis and debt }\end{array}$ & $\begin{array}{l}\text { - Psychiatric diagnosis, } \\
\text { mood disorders, } \\
\text { past attempts, } \\
\text { employment, marital } \\
\text { status, social support }\end{array}$ \\
\hline $\begin{array}{l}\text { Wong et al. } \\
(2010)\end{array}$ & $\begin{array}{l}\text { China } \\
\text { (Hong } \\
\text { Kong) }\end{array}$ & $\begin{array}{l}\text { - Psychological } \\
\text { autopsy } \\
\text { - Case } \\
\text { controlled }\end{array}$ & $\begin{array}{l}\text { - } 150 \text { suicide completers } \\
\text { - } 150 \text { community controls }\end{array}$ & $\begin{array}{l}\text { - Interviews with } \\
\text { relatives of } \\
\text { completers }\end{array}$ & $\begin{array}{l}\text { - All pathological gamblers had } \\
\text { unmanageable debts } \\
\text { - Higher proportion of } \\
\text { unmanageable debt in completers } \\
\text { (without gambling) than control } \\
(22.6 \% \text { vs. } 5.7 \%)\end{array}$ & - None \\
\hline $\begin{array}{l}\text { Wong et al. } \\
(2008)\end{array}$ & $\begin{array}{l}\text { China } \\
\text { (Hong } \\
\text { Kong) }\end{array}$ & $\begin{array}{l}\text { - Psychological } \\
\text { autopsy } \\
\text { - Case } \\
\text { controlled }\end{array}$ & $\begin{array}{l}\text { - } 85 \text { suicide completers } \\
\text { - } 85 \text { community controls }\end{array}$ & $\begin{array}{l}\text { - Interviews with } \\
\text { relatives of } \\
\text { completers } \\
\text { - SCID }\end{array}$ & $\begin{array}{l}\text { - Greater prevalence } \\
\text { unmanageable debt in completers, } \\
\text { aOR of } 9.4\end{array}$ & $\begin{array}{l}\text { - Demographics, } \\
\text { employment, income, } \\
\text { social support, } \\
\text { psychiatric diagnosis, }\end{array}$ \\
\hline
\end{tabular}




\begin{tabular}{|c|c|c|c|c|c|c|}
\hline Study & Country & Design & Sample & Measures Used & Main findings & Confounds controlled \\
\hline & & & & $\begin{array}{l}\text { - Information from } \\
\text { coroners and police } \\
\text { reports }\end{array}$ & & $\begin{array}{l}\text { impulsivity, social } \\
\text { problem solving, } \\
\text { expressed emotion }\end{array}$ \\
\hline
\end{tabular}


Appendix D

Characteristics of Nationally Representative Surveys

\begin{tabular}{|c|c|c|c|c|c|c|}
\hline Study & Country & Design & Sample & Measures Used & Main findings & Confounds controlled \\
\hline $\begin{array}{l}\text { Clark et al. } \\
(2012)\end{array}$ & UK & Cross-sectional & $\begin{array}{l}3383 \\
\text { general } \\
\text { pop. }\end{array}$ & $\begin{array}{l}\text { - CIS-R } \\
\text { - ACQ on work and } \\
\text { life events }\end{array}$ & $\begin{array}{l}\text { - Increased risk of CMD in those in } \\
\text { debt, aOR=1.9 }\end{array}$ & $\begin{array}{l}\text { - Age, gender, house } \\
\text { tenure, marital } \\
\text { status, work stressors } \\
\text { and life events }\end{array}$ \\
\hline $\begin{array}{l}\text { Balmer et al. } \\
(2005)\end{array}$ & $\begin{array}{l}\text { UK } \\
\text { (England } \\
\text { and } \\
\text { Wales) }\end{array}$ & Cross-sectional & $\begin{array}{l}5611 \\
\text { general } \\
\text { pop. }\end{array}$ & $\begin{array}{l}\text { - ACQ on debt and } \\
\text { MH }\end{array}$ & $\begin{array}{l}\text { - Long term illness/disability } \\
\text { significantly predicted legal problems } \\
\text { resulting from debt, and long-term debt } \\
\text { - Little evidence that one predominantly } \\
\text { came first }\end{array}$ & $\begin{array}{l}\text { - Demographics, } \\
\text { qualifications, } \\
\text { benefits, income, } \\
\text { housing }\end{array}$ \\
\hline $\begin{array}{l}\text { Hintikka et al. } \\
\text { (1998) }\end{array}$ & Finland & Cross-sectional & $\begin{array}{l}4868 \\
\text { general } \\
\text { pop. }\end{array}$ & $\begin{array}{l}\text { - ACQ on demographics, } \\
\text { alcohol use and suicidal } \\
\text { ideation } \\
\text { - General Health } \\
\text { Questionnaire-12 }\end{array}$ & $\begin{array}{l}\text { - Those with GHQ of } 3 \text { or more likely } \\
\text { to have debt problems ( } 37 \% \text { vs. } 16 \% \text { ) } \\
\text { - Debt problems increased risk of } \\
\text { suicidal ideation } \\
\text { - No relationship between debt and } \\
\text { suicide attempts }\end{array}$ & $\begin{array}{l}\text { - None } \\
\text { - Mental disorder, } \\
\text { alcohol abuse, } \\
\text { marital separation, } \\
\text { employment }\end{array}$ \\
\hline $\begin{array}{l}\text { Jenkins et al. } \\
(2009)\end{array}$ & $\begin{array}{l}\text { UK } \\
\text { (England } \\
\text { and } \\
\text { Wales) }\end{array}$ & Cross-sectional & $\begin{array}{l}8545 \\
\text { general } \\
\text { pop. }\end{array}$ & $\begin{array}{l}\text { - ACQ on demographics, drug } \\
\text { use, finances } \\
\text { - Psychosis Screening } \\
\text { Questionnaire } \\
\text { - Clinical Assessment in } \\
\text { Neuropsychiatry } \\
\text { - AUDIT } \\
\text { - Severity Alcohol Dependence } \\
\text { Questionnaire }\end{array}$ & $\begin{array}{l}\text { Prevalence of disorder in Debt vs. No } \\
\text { debt groups: } \\
\text { - Any Mental Disorder: } 45 \% \text { vs } 20.4 \% \\
\text { - Neurotic disorder (Depression, OCD, } \\
\text { Panic, GAD): } 32.5 \% \text { vs. } 14.2 \% \\
\text { - Psychotic Disorder: } 1.6 \% \text { vs. } 0.4 \% \\
\text { - Alcohol Dependence: } 15.2 \% \text { vs. } 6.3 \% \\
\text { - Drug Dependence: } 11.5 \% \text { vs. } 2.7 \%\end{array}$ & $\begin{array}{l}\text { - None: descriptives } \\
\text { only }\end{array}$ \\
\hline
\end{tabular}




\begin{tabular}{|c|c|c|c|c|c|c|}
\hline Study & Country & Design & Sample & Measures Used & Main findings & Confounds controlled \\
\hline $\begin{array}{l}\text { Jenkins et al. } \\
(2008)\end{array}$ & UK & Cross-sectional & $\begin{array}{l}8545 \\
\text { general } \\
\text { pop. }\end{array}$ & $\begin{array}{l}\text { - CIS-R } \\
\text { - As per Jenkins } 2009\end{array}$ & $\begin{array}{l}\text { - High prevalence of debt in those with } \\
\text { any mental disorder and neurotic, } \\
\text { psychotic, alcohol and drug } \\
\text { dependence } \\
\text { - Relationships between low income and } \\
\text { and mental disorder partially } \\
\text { moderated by debt } \\
\text { - Debt increased risk after controlling } \\
\text { for income } \\
\text { - Dose-response effect: more debts, } \\
\text { greater risk of mental disorder }\end{array}$ & $\begin{array}{l}\text { - Age, gender, } \\
\text { status, household size, } \\
\text { education, social } \\
\text { class, urban or rural, } \\
\text { region, income }\end{array}$ \\
\hline $\begin{array}{l}\text { Lyons \& } \\
\text { Yilmazer } \\
(2005)\end{array}$ & US & Cross-sectional & $\begin{array}{l}2802 \\
\text { general } \\
\text { pop. }\end{array}$ & - Self-rated health & $\begin{array}{l}\text { - Debt-to-asset ratio did not predict } \\
\text { self-rated health }\end{array}$ & $\begin{array}{l}\text { - Age, ethnicity, } \\
\text { marital status, } \\
\text { employment, receive } \\
\text { benefits, father still, } \\
\text { alive, education } \\
\text { income, smoking } \\
\text { health insurance. }\end{array}$ \\
\hline $\begin{array}{l}\text { Meltzer et al. } \\
(2010)\end{array}$ & UK & Cross-sectional & $\begin{array}{l}3581 \\
\text { general } \\
\text { pop. }\end{array}$ & - CIS-R & $\begin{array}{l}\text { - Being in debt associated with } \\
\text { depression, aOR: } 2.2\end{array}$ & - Age and gender \\
\hline $\begin{array}{l}\text { Meltzer et al. } \\
(2011)\end{array}$ & UK & Cross-sectional & $\begin{array}{l}7461 \\
\text { general } \\
\text { pop. }\end{array}$ & $\begin{array}{l}\text { - ACQ on finances, suicidal } \\
\text { ideation and behaviours }\end{array}$ & $\begin{array}{l}\text { - Being in debt increased risk of } \\
\text { suicidal ideation, aOR }=2.0 \\
\text { - Feelings of hopelessness partially } \\
\text { mediated relationship }\end{array}$ & $\begin{array}{l}\text { - Age, gender, } \\
\text { marital status, } \\
\text { employment, } \\
\text { drinking, gambling, }\end{array}$ \\
\hline
\end{tabular}




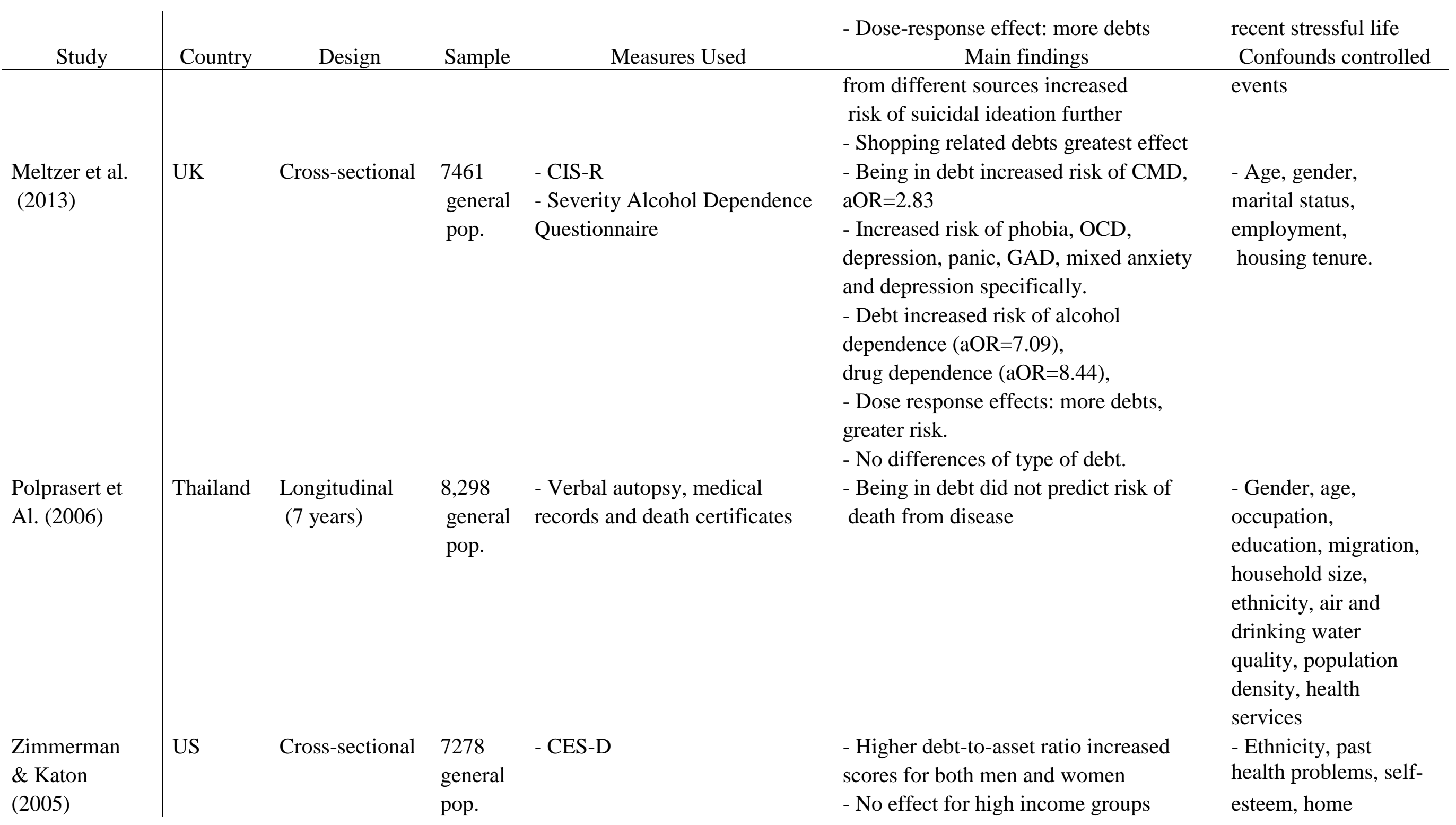


ownership, marital Confounds controlled status, children, insurance, home ownership, employment, occupation

Abbreviations: $\mathrm{ACQ}=$ Author Constructed Questions, $\mathrm{CMD}=$ Common Mental Disorders, pop.=population, CIS-R=Clinical Interview Schedule Revised, aOR=Adjusted Odds Ratios, $\mathrm{OCD}=$ Obsessive Compulsive Disorder, GAD=Generalized Anxiety Disorder. 
Appendix E

Characteristics of studies with Health Service User Populations

\begin{tabular}{|c|c|c|c|c|c|c|}
\hline Study & Country & Design & Sample & Measures Used & Main findings & Confounds controlled \\
\hline $\begin{array}{l}\text { Abbo et al. } \\
(2008)\end{array}$ & Uganda & $\begin{array}{l}\text { Cross- } \\
\text { Sectional }\end{array}$ & $\begin{array}{l}\text { - } 387 \text { attending } \\
\text { traditional } \\
\text { healers }\end{array}$ & $\begin{array}{l}\text { - Self Reporting } \\
\text { Questionnaire-20 }\end{array}$ & $\begin{array}{l}\text { - } 84.3 \% \text { of distressed in debt vs. } 5.7 \% \\
\text { non-distressed, OR=2.5 }\end{array}$ & - None \\
\hline $\begin{array}{l}\text { Patel et al. } \\
(1998)\end{array}$ & India & $\begin{array}{l}\text { Cross- } \\
\text { Sectional }\end{array}$ & $\begin{array}{l}\text { - } 303 \text { primary } \\
\text { health attenders }\end{array}$ & $\begin{array}{l}\text { - ACQ on finances and } \\
\text { demographics } \\
\text { - CIS-R }\end{array}$ & - Debt predicted CMD: aOR=2.8 & $\begin{array}{l}\text { - Gender, education, } \\
\text { employment, poverty, } \\
\text { widowed, religion }\end{array}$ \\
\hline $\begin{array}{l}\text { Pothen et al. } \\
(2003)\end{array}$ & India & $\begin{array}{l}\text { Cross- } \\
\text { Sectional }\end{array}$ & $\begin{array}{l}\text { - } 303 \text { primary } \\
\text { health attenders }\end{array}$ & $\begin{array}{l}\text { - ACQ on finances and } \\
\text { demographics } \\
\text { - CIS-R }\end{array}$ & $\begin{array}{l}\text { - Debt predicted CMD: aOR=2.1 } \\
\text { - Debt predicted Depression: } a \mathrm{OR}=2.4\end{array}$ & - Age, gender, poverty \\
\hline Hatcher (1994) & UK & $\begin{array}{l}\text { Cross- } \\
\text { Sectional }\end{array}$ & $\begin{array}{l}\text { - } 147 \text { self- } \\
\text { harmers } \\
\text { presenting to } \\
\text { hospital }\end{array}$ & $\begin{array}{l}\text { - ACQ on debt } \\
\text { - Beck Suicide Intent } \\
\text { Scale } \\
\text { - Risk of Repetition } \\
\text { Scale } \\
\text { - Beck Depression } \\
\text { Inventory } \\
\text { - Beck Hopelessness } \\
\text { Scale } \\
\text { - GHQ-30 }\end{array}$ & $\begin{array}{l}\text { - Those with debt sig. higher scores on } \\
\text { suicidal intent, depression, GHQ, } \\
\text { hopelessness. } \\
\text { - No difference on risk of repetition } \\
\text { - Those in debt more likely to receive } \\
\text { psychiatric diagnosis ( } 91 \% \text { vs. } 71 \% \text { ) }\end{array}$ & - None \\
\hline $\begin{array}{l}\text { Battersby et al. } \\
(2006)\end{array}$ & Australia & $\begin{array}{l}\text { Cross- } \\
\text { Sectional }\end{array}$ & $\begin{array}{l}-43 \\
\text { gambling } \\
\text { outpatients }\end{array}$ & $\begin{array}{l}\text { - Suicide Ideation Scale } \\
\text { - ACQ demographics } \\
\text { and debt }\end{array}$ & $\begin{array}{l}\text { - Debt from gambling increased risk of } \\
\text { suicidal ideation and attempts }\end{array}$ & - None \\
\hline
\end{tabular}




\begin{tabular}{l|ccccc}
\multicolumn{1}{c|}{ Study } & Country & \multicolumn{1}{c}{ Design } & \multicolumn{1}{c}{ Sample } & \multicolumn{1}{c}{ Measures Used } & \multicolumn{1}{c}{ Main findings } \\
\hline $\begin{array}{l}\text { Maccallum \& } \\
\text { Blaszczynski } \\
(2003)\end{array}$ & Australia & $\begin{array}{l}\text { Cross- } \\
\text { Sectional }\end{array}$ & $\begin{array}{l}-85 \\
\text { gambling } \\
\text { outpatients }\end{array}$ & $\begin{array}{l}\text { - Beck Scale for } \\
\text { Suicide Ideation }\end{array}$ & $\begin{array}{l}\text { - No difference in amount of gambling } \\
\text { debt based on presence or absence of } \\
\text { suicidal ideation }\end{array}$ \\
\hline $\begin{array}{l}\text { Abbreviations: ACQ= Author Constructed Questions, CMD=Common Mental Disorders, CIS-R=Clinical Interview Schedule Revised, } \\
\text { aOR=Adjusted Odds Ratios. }\end{array}$
\end{tabular}


Appendix F

Characteristics of studies with Debt Management Clients

\begin{tabular}{|c|c|c|c|c|c|c|}
\hline Study & Country & Design & Sample & Measures Used & Main findings & Confounds controlled for \\
\hline $\begin{array}{l}\text { Münster et al. } \\
\text { (2009) }\end{array}$ & Germany & $\begin{array}{l}\text { - Cross-sectional } \\
\text { - Cohort study }\end{array}$ & $\begin{array}{l}\text { - } 949 \text { debt } \\
\text { counselling } \\
\text { clients } \\
\text { - } 8318 \text { general } \\
\text { pop. }\end{array}$ & $\begin{array}{l}\text { - ACQ demographics, } \\
\text { smoking, depression } \\
\text { - BMI }\end{array}$ & $\begin{array}{l}\text { - Over-indebted more likely to be } \\
\text { overweight, } \mathrm{aOR}=2.6\end{array}$ & $\begin{array}{l}\text { - Age, gender, education, } \\
\text { income, depression, } \\
\text { smoking }\end{array}$ \\
\hline Ochsmann et al. & Germany & $\begin{array}{l}\text { - Cross-sectional } \\
\text { - Cohort study }\end{array}$ & - As per Münster & $\begin{array}{l}\text { - ACQ medical } \\
\text { problems, debt, back } \\
\text { Pain }\end{array}$ & $\begin{array}{l}\text { - Over-indebted more likely to } \\
\text { report back pain, aOR=10.9 }\end{array}$ & $\begin{array}{l}\text { - Age, education, marital } \\
\text { status, employment, } \\
\text { mental illness, BMI, } \\
\text { physical activity }\end{array}$ \\
\hline $\begin{array}{l}\text { O'Neill et al. } \\
(2005)\end{array}$ & US & $\begin{array}{l}\text { - Intervention } \\
\text { trial } \\
\text { (case series) }\end{array}$ & $\begin{array}{l}\text { - } 3121 \text { debt } \\
\text { management } \\
\text { clients }\end{array}$ & $\begin{array}{l}\text { - ACQ on finances } \\
\text { - Self-rated health }\end{array}$ & $\begin{array}{l}\text { - Those who reported improve } \\
\text { health more likely to have reduced } \\
\text { their debts ( } 57 \% \text { vs } 40 \%)\end{array}$ & - None \\
\hline $\begin{array}{l}\text { Selenko \& } \\
\text { Batinic (2011) }\end{array}$ & Austria & - Cross-sectional & $\begin{array}{l}-106 \text { debt } \\
\text { counselling } \\
\text { clients }\end{array}$ & $\begin{array}{l}\text { - ACQ on financial } \\
\text { strain } \\
\text { - General Health } \\
\text { Questionnaire }\end{array}$ & $\begin{array}{l}\text { - No correlation between amount of } \\
\text { and MH } \\
\text { - Sig. correlation between financial } \\
\text { strain and MH }\end{array}$ & - None \\
\hline
\end{tabular}

Abbreviations: $\mathrm{ACQ}=$ Author Constructed Questions, $\mathrm{BMI}=$ Body Mass Index, aOR=Adjusted Odds Ratios. 
Appendix G

Characteristics of studies with Older Adults

\begin{tabular}{|c|c|c|c|c|c|c|}
\hline Study & Country & Design & Sample & Measures Used & Main findings & Confounds controlled \\
\hline $\begin{array}{l}\text { Kaji et al. } \\
(2010)\end{array}$ & Japan & $\begin{array}{l}\text { Cross- } \\
\text { sectional }\end{array}$ & $\begin{array}{l}-10,969 \text { general. } \\
\text { pop. older adults } \\
(50+)\end{array}$ & $\begin{array}{l}\text { - ACQ on life } \\
\text { and debt } \\
\text { - CES-D }\end{array}$ & $\begin{array}{l}\text { - Debt sig. predicted mild-moderate } \\
(\mathrm{aOR}=1.3) \text { and severe }(\mathrm{aOR}=2.1) \\
\text { depression }\end{array}$ & $\begin{array}{l}\text { - Gender, age, city vs rural } \\
\text { region. }\end{array}$ \\
\hline $\begin{array}{l}\text { Lee \& } \\
\text { Brown } \\
(2007)\end{array}$ & US & $\begin{array}{l}\text { Cross- } \\
\text { sectional }\end{array}$ & $\begin{array}{l}\text { - } 8845 \text { general } \\
\text { pop. older adults } \\
(65+)\end{array}$ & - 8 items from CES- & - Being in debt sig. predicted depression & $\begin{array}{l}\text { - Age, marital status, } \\
\text { education, ethnicity, } \\
\text { employment, physical } \\
\text { health, income }\end{array}$ \\
\hline $\begin{array}{l}\text { Lee et al. } \\
(2007)\end{array}$ & US & $\begin{array}{l}\text { Cross- } \\
\text { sectional }\end{array}$ & $\begin{array}{l}\text { - } 9996 \text { general } \\
\text { pop. older adults } \\
(65+)\end{array}$ & $\begin{array}{l}\text { - ACQ finances and } \\
\text { Health } \\
\text { - Self-rated health }\end{array}$ & $\begin{array}{l}\text { - No effect of self-rated health on } \\
\text { consumer debt }\end{array}$ & $\begin{array}{l}\text { Gender, age, family size, } \\
\text { education, income, marital } \\
\text { status, ethnicity, } \\
\text { employment, housing } \\
\text { tenure }\end{array}$ \\
\hline $\begin{array}{l}\text { Drentea \& } \\
\text { Reynolds } \\
(2012)\end{array}$ & US & $\begin{array}{l}\text { - Panel } \\
\text { - Two } \\
\text { points }\end{array}$ & $\begin{array}{l}-1,463 \text { general } \\
\text { pop. older adults } \\
\text { - Mean age }=59\end{array}$ & $\begin{array}{l}\text { - CES-D } \\
\text { - ACQ anxiety and }\end{array}$ & $\begin{array}{l}\text { - Depression and anxiety sig. predicted } \\
\text { by debt } \\
\text { - Debt more strongly related than income } \\
\text { or assets } \\
\text { - Stress about debt moderated relationship }\end{array}$ & $\begin{array}{l}\text { Gender, age, ethnicity, } \\
\text { employment, health } \\
\text { insurance, marital status, } \\
\text { physical disability, } \\
\text { children }\end{array}$ \\
\hline
\end{tabular}

Abbreviations: $\mathrm{ACQ}=$ Author Constructed Questions, $\mathrm{aOR}=$ Adjusted Odds Ratios, pop.=population, $\mathrm{CESD}=$ Centre for Epidemiological Studies

Depression Scale. 
Appendix $\mathrm{H}$

Characteristics of studies with other Specific Populations

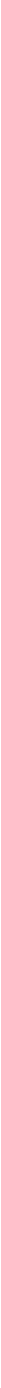




\begin{tabular}{|c|c|c|c|c|c|c|}
\hline Study & Country & Design & Sample & Measures Used & Main findings & Confounds controlled for \\
\hline $\begin{array}{l}\text { Drentea \& } \\
\text { Lavrakas (2000) }\end{array}$ & US & - Cross-sectional & $\begin{array}{l}-970 \text { general } \\
\text { pop. } \\
-16.5 \% \text { ethnic } \\
\text { minority }\end{array}$ & $\begin{array}{l}\text { - Self-rated health } \\
\text { - Adapted Physical } \\
\text { Performance Scale } \\
\text { - BMI } \\
\text { - ACQ smoking, } \\
\text { drinking, debt. }\end{array}$ & $\begin{array}{l}\text { Physical performance sig. predicted by: } \\
\text { - Debt/income ratio and debt stress } \\
\text { - No effect of amount of credit, number of } \\
\text { of cards, defaulting or carrying a balance } \\
\text { forward } \\
\text { - Self-rated health sig. predicted by debt } \\
\text { stress index and carrying a balance } \\
\text { forward } \\
\text { - No effect of debt/income ratio, amount } \\
\text { of credit, number of cards or default } \\
\text { - BMI, smoking and drinking moderated } \\
\text { effect of debt/income on self-rated } \\
\text { health }\end{array}$ & $\begin{array}{l}\text { - Gender, age, } \\
\text { education, ethnicity, } \\
\text { employment, SES, } \\
\text { income, BMI } \\
\text { smoking, drinking }\end{array}$ \\
\hline Yao et al. (2011) & US & - Cross-sectional & $\begin{array}{l}\text { - } 149 \text { Chinese } \\
\text { Americans }\end{array}$ & $\begin{array}{l}\text { - ACQ on debt } \\
\text { - Self-rated health }\end{array}$ & $\begin{array}{l}\text { - Non significant trend }(p<.10) \text { for better } \\
\text { health to increase likelihood of debt }\end{array}$ & $\begin{array}{l}\text { - Age, gender, children, } \\
\text { assets, income. }\end{array}$ \\
\hline $\mathrm{Xu}(2011)$ & US & - Cross-sectional & $\begin{array}{l}\text { - } 1941 \text { Latino } \\
\text { Americans }\end{array}$ & $\begin{array}{l}\text { - Items from K-10 } \\
\text { scale of } \\
\text { psychological } \\
\text { distress } \\
\text { - ACQ on finances }\end{array}$ & $\begin{array}{l}\text { - Debt predicted distress in Cubans and } \\
\text { Puerto Ricans } \\
\text { - No relationship for Mexicans }\end{array}$ & $\begin{array}{l}\text { Age, gender, physical } \\
\text { health, discrimination, } \\
\text { income }\end{array}$ \\
\hline \multicolumn{7}{|l|}{ Farmers } \\
\hline $\begin{array}{l}\text { Besler \& } \\
\text { Stallones (2008) }\end{array}$ & US & $\begin{array}{l}\text { - Longitudinal } \\
\text { (3 years) }\end{array}$ & $\begin{array}{l}\text { - } 872 \text { farmers } \\
\text { and their spouses }\end{array}$ & $\begin{array}{l}\text { - CES-D } \\
\text { - ACQ on finances }\end{array}$ & $\begin{array}{l}\text { - Recent increase in debt increased risk } \\
\text { of depression, aOR: } 1.9\end{array}$ & $\begin{array}{l}\text { Gender, age, marital } \\
\text { status, income, health, } \\
\text { pesticide poisoning }\end{array}$ \\
\hline $\begin{array}{l}\text { Berry et al. } \\
\text { (2011) }\end{array}$ & Australia & - Cross-sectional & - 3993 farmers & $\begin{array}{l}\text { - ACQ finances, } \\
\text { demographics }\end{array}$ & $\begin{array}{l}\text { - Greater debt pressure sig. predicted } \\
\text { better self-rated health }\end{array}$ & $\begin{array}{l}\text { - Age, education, } \\
\text { farming related }\end{array}$ \\
\hline
\end{tabular}


Abbreviations: $\mathrm{ACQ}=$ Author Constructed Questions, CIS-R=Clinical Interview Scheduled Revised, aOR=Adjusted Odds Ratios, pop.=population, $\mathrm{CESD}=$ Centre for Epidemiological Studies Depression Scale, $\mathrm{CMD}=\mathrm{Common}$ Mental Disorders, BMI=Body Mass Index. 
Appendix I

Characteristics other Studies

\begin{tabular}{|c|c|c|c|c|c|c|}
\hline Study & Country & Design & Sample & Measures Used & Main findings & Confound controlled \\
\hline $\begin{array}{l}\text { Elbogen et al. } \\
(2012)\end{array}$ & US & $\begin{array}{l}\text { Cross- } \\
\text { sectional }\end{array}$ & $\begin{array}{l}-1,388 \\
\text { veterans post- } \\
\text { deployment }\end{array}$ & $\begin{array}{l}\text { - Davidson Trauma } \\
\text { Scale } \\
\text { - Patient Health } \\
\text { Questionnaire } \\
\text { - ACQ on brain } \\
\text { injury and finances }\end{array}$ & $\begin{array}{l}\text { - Those with Major Depressive } \\
\text { Depressive Disorder, Post Traumatic } \\
\text { Stress Disorder or Traumatic Brain } \\
\text { Injury sig. likely to have unsecured } \\
\text { debt over } \$ 40 \mathrm{k}(13 \% \text { vs. } 8 \%)\end{array}$ & - None \\
\hline $\begin{array}{l}\text { Finlay-Jones \& } \\
\text { Eckhardt (1984) }\end{array}$ & Australia & $\begin{array}{l}\text { Cross- } \\
\text { sectional }\end{array}$ & $\begin{array}{l}\text { - } 401 \\
\text { unemployed } \\
\text { young people } \\
\text { (age 16-24) }\end{array}$ & $\begin{array}{l}\text { - GHQ-30 } \\
\text { - Present State } \\
\text { Examination } \\
\text { - ACQ finances, } \\
\text { demographics, }\end{array}$ & $\begin{array}{l}\text { - Debt sig. predicted being above cut-off } \\
\text { on GHQ in men but not women }\end{array}$ & $\begin{array}{l}\text { - Gender, able to } \\
\text { borrow money, } \\
\text { resigning from job, } \\
\text { dismissed from work, } \\
\text { saving. }\end{array}$ \\
\hline $\begin{array}{l}\text { Kassim \& } \\
\text { Croucher (2006) }\end{array}$ & UK & $\begin{array}{l}\text { Cross- } \\
\text { sectional }\end{array}$ & $\begin{array}{l}\text { - } 75 \text { male from } \\
\text { Yemen } \\
\text { background }\end{array}$ & $\begin{array}{l}\text { - ACQ: khat use, } \\
\text { demographics } \\
\text { - Severity of } \\
\text { Dependence Scale }\end{array}$ & $\begin{array}{l}\text { - Those dependent on khat sig. more } \\
\text { likely to be in debt to khat seller } \\
(37.9 \% \text { vs } 17.4 \%)\end{array}$ & - None \\
\hline $\begin{array}{l}\text { Molander et al. } \\
(2010)\end{array}$ & US & $\begin{array}{l}\text { - Longitudinal } \\
\text { - } 2 \text { time } \\
\text { points } 11 \\
\text { years apart }\end{array}$ & $\begin{array}{l}-5,283 \text { adults } \\
\text { Age } 53\end{array}$ & - ACQ on drinking & $\begin{array}{l}\text { - No effect of debt on changes across } \\
\text { time in drinking in the past month, } \\
\text { number drinking days, drinks a day, } \\
\text { total drinks } \\
\text { - Those who experienced debt more } \\
\text { likely to change from heavy to not } \\
\text { heavy drinking, aOR: } 1.8\end{array}$ & $\begin{array}{l}\text { Gender, education, } \\
\text { high school IQ, } \\
\text { employment, marital } \\
\text { status, income } \\
\text { physical health, } \\
\text { depression }\end{array}$ \\
\hline Patel et al. (2005) & India & Cross- & -3000 women & - ACQ on health and & - Being in debt related to presence of & - Age, education, \\
\hline
\end{tabular}




\begin{tabular}{|c|c|c|c|c|c|c|}
\hline Study & Country & Design & Sample & Measures Used & Main findings & Confound controlled \\
\hline & & sectional & & $\begin{array}{l}\text { and debt } \\
\text { - Scale for somatic } \\
\text { symptoms } \\
\text { - CIS-R }\end{array}$ & chronic fatigue syndrome, aOR: 1.3 & $\begin{array}{l}\text { literacy, marital } \\
\text { status, poverty } \\
\text { (hunger, toilet and } \\
\text { tap water in house) }\end{array}$ \\
\hline $\begin{array}{l}\text { Hainer \& Palesch } \\
\text { (1998) }\end{array}$ & US & $\begin{array}{l}\text { - Longitudinal } \\
-2.5 \text { years }\end{array}$ & $\begin{array}{l}-350 \text { Doctors } \\
\text { (family practice } \\
\text { residents) }\end{array}$ & $\begin{array}{l}\text { - Beck Depression } \\
\text { Inventory } \\
\text { - Profile of Mood } \\
\text { States }\end{array}$ & $\begin{array}{l}\text { - No effect of indebtedness on } \\
\text { depression }\end{array}$ & - Details not given \\
\hline $\begin{array}{l}\text { Saxena et al. } \\
(2003)\end{array}$ & India & $\begin{array}{l}\text { - Cross- } \\
\text { sectional } \\
\text { - Cohort } \\
\text { Study }\end{array}$ & $\begin{array}{l}\text { - Slum-dwelling } \\
\text { families } \\
\text { - } 98 \text { with heavy } \\
\text { drinker, } 99 \\
\text { without }\end{array}$ & $\begin{array}{l}\text { - ACQ } \\
\text { demographics, } \\
\text { drinking }\end{array}$ & $\begin{array}{l}\text { - Families with a drinker sig. more } \\
\text { likely to be in significant debt }(54 \% \\
\text { Vs. } 29 \%) \\
\text { - Debt-to-income ratio sig higher for } \\
\text { drinking group }\end{array}$ & - None \\
\hline $\begin{array}{l}\text { Turvey et al. } \\
(2002)\end{array}$ & US & $\begin{array}{l}\text { Cross- } \\
\text { sectional }\end{array}$ & $\begin{array}{l}-1617 \text { rural } \\
\text { inhabitants }\end{array}$ & $\begin{array}{l}\text { - ACQ on suicide } \\
\text { and debt }\end{array}$ & $\begin{array}{l}\text { - Those with recent increase in debt sig. } \\
\text { more likely to have had suicidal } \\
\text { thoughts }\end{array}$ & - None \\
\hline
\end{tabular}

Abbreviations: ACQ=Author Constructed Questions, aOR=Adjusted Odds Ratios, GHQ=General Health Questionnaire. 